\title{
Inoculation with Pisolithus tinctorius may ameliorate acid rain impacts on soil microbial communities associated with Pinus massoniana seedlings
}

Running Head:

EM inoculation and acid rain on soil abiotic and biotic conditions.

Mia R. Maltz ${ }^{* 1,3}$, Zhan Chen ${ }^{*}+2$, Jixin $\mathrm{Cao}^{2}$, Keshav Arogyaswamy ${ }^{1}$, Hannah Shulman ${ }^{1}$, Emma L. Aronson ${ }^{1,3}$

${ }^{1}$ Department of Microbiology and Plant Pathology, University of California, Riverside, California, United States of America

${ }^{2}$ Laboratory of Forest Ecology and Environment of State Forestry Administration, Institute of Forest Ecology, Environment, and Protection, Chinese Academy of Forestry, Beijing,

China

${ }^{3}$ Center for Conservation Biology, University of California, Riverside, California, United

States of America

Co-first Authors, denotes equal author contributions

${ }^{\dagger}$ Corresponding Author: Zhan Chen (chenzhan0508@126.com)

Please direct email correspondence to: maltz@ucr.edu (MM), in care of Zhan Chen; Telephone: 707-478-3921 (MM); Website: http://sites.uci.edu/maltz/ (MM)

Submitted for publication in Fungal Ecology in 2018 


\begin{abstract}
Human activities accelerate acidification, particularly as acid rain, which may have lasting impacts on soil abiotic and biotic parameters. However, the effects of acidification on aboveground vegetation, belowground communities, and carbon cycling remains unresolved. We examined the effects of long-term acidic treatments and Pisolithus inoculation on plants, soils, and microbial communities in pine plantations and found that exposure to severely-acidic treatments diminished plant performance, altered microbial communities, and decreased organic matter, nitrate, and available phosphorus. Although we did not detect any benefits of Pisolithus inoculation for Pinus seedlings impacted by severely-acidic treatments, when these severe treatments were inoculated with Pisolithus, both soil properties and microbial community composition shifted. We posit that inoculation with Pisolithus may alleviate stressful environmental conditions, and change the structure of mycorrhizal fungal communities. Although acidification may alter biogeochemical cycles and constrain aboveground and belowground communities, Pisolithus inoculation may provide benefits to some components of forested ecosystems.
\end{abstract}

\title{
Index descriptors:
}

Ectomycorrhizal, Inoculation, Acidification, Biogeochemical cycling, Microbial

Communities, Fungal Community Composition, Pinus massoniana, Pisolithus. 


\section{Introduction}

Microbes play a critical role in biogeochemical cycling as regulators of decomposition, plant-microbe interactions, and nutrient transformations (van der Heijden et al. 2008). However, microbial processes are threatened by human activities and industrial inputs to ecosystems, such as sulfur (S) and nitrogen (N) deposition, which result in landscape degradation and biodiversity loss (Bobbink et al. 2010, Allen et al. 2016). Industrial inputs can acidify soils, further threatening microbial processes and ecosystem functions. Accelerated acidification in forest soils via acid deposition from anthropogenic sources may have lasting impacts on soil physicochemical properties and biotic communities. For example, deposition from industrial emissions on forests in Europe (Jandl et al. 2012) and North America (Reininger et al. 2011) have been linked to long-lasting disruptions in biotic communities and biogeochemical cycling (Likens et al. 1996). However, the long-term effects and the degree to which industrial inputs leading to soil acidification impacts belowground carbon cycling via shifts in plant and soil microbial community composition in terrestrial ecosystems is not yet resolved.

While variable, acid rain generally reduces plant productivity by damaging foliar tissue (Neufeld et al. 1985), reducing biomass (Raschke 1975), diminishing resource availability to plants (Bååth \& Arnebrandt 1994), and disrupting essential physiological processes including stomatal functioning (Zieger et al. 1983) and chlorophyll production (Odiyi and Bamidele 2013). Acid deposition dissolves nutrients and 
divalent cations, such as magnesium (Mg) and calcium (Ca) (Berger et al. 2016, Leys et al. 2016, Türtscher et al. 2017), while facilitating aluminum (Al) release which could reduce plant root growth and inhibit plant nutrient uptake (Burnham et al. 2017). By stripping soils of nutrients, hindering soils' capacity to buffer plants from toxic substances, and physically harming aboveground vegetation, acid deposition can reduce plant productivity through malnourishment, dehydration (Macaulay et al. 2015), or toxicity.

By constraining plant productivity, acidification could indirectly alter the composition of fungal communities and hamper soil microbial processes, with implications for organic carbon storage in forested ecosystems (Kemmitt et al. 2006, Janssens et al. 2010, Oulehle et al. 2011). Even though the consequences of these inputs on soil organic matter (SOM) content have been inconsistent (Averill \& Waring 2017, Liu et al. 2011, Mack et al. 2004), reductions in microbial $\mathrm{CO}_{2}$ efflux and soil organic carbon turnover associated with soil acidification could lead to SOM accumulation (Tonneijic et al. 2010) by inhibiting decomposition of woody debris (Ferreira et al. 2017), and by influencing microbial physiology (Chen et al. 2016), growth (Rousk et al. 2010), and activity (Anderson \& Domsch 1993).

Through damaging plant communities, acidification in soil could also interfere with the functioning of plant symbionts, such as mycorrhizal fungi (Carrino-Kyker et al. 2016). Ectomycorrhizal fungi (EM) play essential roles in forested ecosystems (McNear Jr. 2013), such as soil exploration and mineral weathering, and by acting as a 
link between aboveground and belowground components of biogeochemical cycles (Treseder \& Allen 2000). A subset of EM fungi produces extracellular enzymes (Feng 1993, Bodeker et al. 2009), which amplify the bioavailability of rhizosphere nutrients (Courty et al. 2005, 2010a, Talbot et al. 2015). Because EM fungi obtain a majority of their $\mathrm{C}$ from live plants, mycorrhizal biomass and resource allocation patterns are largely reliant on the vitality of plant foliage. Previous studies have shown that acidifying pollutants extensively damage forest tree roots and EM fungi (Sobotka 1964, Stroo and Alexander 1985), via increased metal toxicity or foliar deterioration. These effects likely limit photosynthetic capacity, carbohydrate flux to roots, and mycorrhizal function (Dighton \& Jansen 1991). As soil pH plays an important role in regulating EM turnover (Glassman et al. 2017, Molina \& Trappe 1982), acid-induced changes in soil chemistry can also directly alter EM community structure (Markkola \& Ohtonen 1998), diversity (Kluber et al. 2012), and hyphal length (Dighton \& Skeffington 1987). Although EM fungi aid their host plants in efficiently acquiring nutrients (Nara et al. 2003, Qu et al. 2010, Chorianopoulou et al. 2015), acidic inputs that reduce plant diversity (Bobbink et al. 2010) or alter plant performance may also indirectly reduce ectomycorrhizal growth and EM root colonization (Arnolds 1988, Wallenda \& Kottke 1998).

Along with EM fungal communities and functions, other microbial groups may also be sensitive to the effects of acidification. The diversity and relative abundances of some bacterial taxa, such as Acidobacteria, Actinobacteria, and Bacteriodetes, 
change predictably across soil acidity gradients (Jones et al. 2009). Although a number of bacterial taxa may be excluded from acidic environments, such as acid-impacted lakes, several bacterial taxa, including Alphaproteobacteria may thrive at low $\mathrm{pH}$ (Percent et al. 2008). Previous studies have shown that $\mathrm{pH}$ is an accurate predictor of soil bacterial community structure across large spatial scales (Lauber et al. 2009, Landesman et al. 2014). In their biogeographic survey across the Western Hemisphere, Fierer and Jackson (2006), found that the most acidic soils in the Peruvian Amazon had lowest bacterial diversity. In a biogeographic assessment across Great Britain, Griffiths et al. (2011) similarly showed a positive relationship between alpha diversity and soil $\mathrm{pH}$; conversely, in the same study, beta diversity was greatest in acidic soils.

Saprotrophic fungal communities may differ as soil and plant-litter chemistries change (Prewitt et al. 2014). Surveys of macrofungal fruitbodies showed that ratios of saprotrophic to mycorrhizal fungi tend to increase when forests decline in productivity (Fellner \& Pešková 1995). Factors that reduce forest productivity could either reduce the relative abundance of mycorrhizal fungi or increase the percentage of decomposer fungi in the fungal community, with implications for forest nutrient cycling.

As ecosystems recover from long-term effects of acidification, both aboveground and belowground components of ecosystems may benefit from active mycorrhizal restoration via EM inoculation to augment revegetation efforts (Leake 2001). 
Inoculation with EM fungi may improve tree performance and promote ecosystem recovery from long-term acidification. Some EM, such as Pisolithus, grow well in acidic environments, like acidic strip mine sites (Hendrix et al. 1985, Liang et al.1999, Baroglio et al. 2000). Mycorrhizal fungi may not only assist host trees in acquiring macronutrients (Virant-Klan \& Gogala 1995, Chuyong et al. 2000), but may also buffer plants from the effects of acid rain. However, little is known about the levels of soil acidity which effectively diminish the capacity of EM fungi to associate with or provide benefits to their plant hosts. Although belowground communities may predictably respond to acidic inputs, direct restoration of soil microbes and plant-associated fungi may foster ecosystem succession towards alternative stable states within recently restored systems (Lewontin 1969, Rustad et al. 1996, Bardhan et al. 2012). An explicit consideration of both fungal and bacterial communities may provide valuable metrics for directing conservation efforts and assessing soil ecosystem recovery from acidification in forested ecosystems (Baldrian et al. 2012).

Acid rain inputs and soil acidification are major concerns in Asia (Zhao et al. 2009, Yang et al. 2012). China is a prime example of acidification because most ecosystems in southern China receive large quantities of acidic inputs (Zhang et al. 2012). In southern China, acid rain has detrimentally affected plant and soil traits (e.g., Fan \& Wang 2000, Wang et al. 2009, Zhang et al. 2007, Lv et al. 2014). Yet, little is known about the long-term impacts of acid rain on soil microbial communities and 
biogeochemical cycling in forested ecosystems, or whether microbial inoculation ameliorates these effects on Chinese forests.

Pinus massoniana is a widespread native pine species in central and southern China. To compensate for the loss of natural forests in southern China, P. massoniana is commonly grown in pine plantations. This tree forms EM associations with a number of EM fungal taxa. However, P. massoniana is sensitive to acid rain (Yu et al. 2017) and may benefit from strategies lessening the impact of acidification on pine forests. Our previous experiments in southern China showed that inoculation with the EM taxon Pisolithus tinctorius may ameliorate the effects of acidification and improve the growth of Pinus massoniana seedlings under different acid rain treatments (Chen et al. 2013, Chen \& Shang 2014).

To examine the long-term effects of acid rain treatments on plant and soil properties and microbial communities and to evaluate the extent to which these effects are ameliorated by ectomycorrhizal inoculation in forested ecosystems in southern China, we experimentally addressed the following questions: (1) Does acid rain have inhibitory effects on plant, soil, and microbial communities? And (2), does active mycorrhizal restoration increase plant growth, improve soil properties, and promote microbial diversity following protracted acid rain exposure? To approach these questions, we first investigated the effects of acidic treatments on plant performance in a forested ecosystem in southern China by evaluating soil properties, nutrient concentrations, and soil organic matter in both acid-treated and inoculated treatment 
plots. Next, we examined fungal and bacterial communities to determine whether Pisolithus inoculation ameliorated the effects of acid treatments on soil microbial communities and plant hosts. We hypothesized that in acidic treated P. massoniana plots (1) plant performance would decline, (2) both soil nutrients and soil organic matter would decrease, and (3) soil microbial communities would be altered. If acidification reduces the abundance or functioning of EM fungi, then $P$. massoniana seedlings may struggle to persist in pine plantations without fungal mutualists. Therefore, we hypothesized that (4) inoculation with Pisolithus would facilitate better tree growth and resilience than acid-treated trees without Pisolithus, along with associated changes to soil properties, biogeochemical cycling, and microbial communities in acid-treated Pisolithus inoculated plots.

\section{Materials and Methods}

\section{Study system}

We investigated the effects of acidic treatments on plants, soils, and microbial communities in experimental plots planted with Pinus massoniana in Changsha

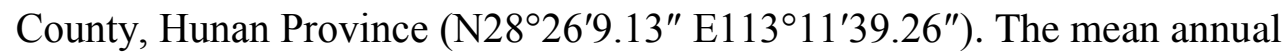
temperature is $17.2^{\circ} \mathrm{C}$ and mean annual precipitation at our study site is $1422.4 \mathrm{~mm}$. This location is frequently exposed to acidic precipitation, with a mean annual $\mathrm{pH}$ of precipitation of 5.02 (Environmental Quality of Hunan Province in 2016 by Environmental Protection Department of Hunan, hnhbt.hunan.gov.cn ). Prior to 
treatment, the $\mathrm{pH}$ of field soils at our experimental site were $5.73 \pm 0.13$ (Table 1, Supplemental Table SI1).

Our experimental plots were located within a cleared field which was previously cultivated, but allowed to lay fallow for four years prior to our study. Prior to initiating our experimental treatments, in March 2015 we analyzed baseline soil nutrients within our field plots and found that soils contained total $\mathrm{N}$ of $0.13 \mathrm{~g} \mathrm{~kg}^{-1}$, Olsen phosphorus (P) of $28.59 \mathrm{mg} \mathrm{kg}^{-1}$, and an available potassium (K) of $31.5 \mathrm{mg} \mathrm{kg}^{-1}$. Using a total organic carbon (TOC) analyzer, we found that soil organic matter was $20.28 \mathrm{~g} \mathrm{~kg}^{-1}$. We constructed eighteen $6 \mathrm{~m}^{2}$ experimental plots; each plot was covered with a canopy, which extended $5 \mathrm{~m}$ above the plots. This canopy enclosed our experimental plots, thus preventing natural precipitation from directly reaching soil surfaces. Outside of each treatment plot, we left an untreated $0.5 \mathrm{~m}-0.6 \mathrm{~m}$ gap surrounding each edge of each treatment plot.

\section{Inoculation treatment}

In March 2013, Pinus massoniana seedlings were inoculated with either

Pisolithus tinctorius EM fungal inoculum (Pisolithus tinctorus [Pers.] Coker et Couch; Sclerodermatacea) or sterilized P. tinctorius material. Pisolithus tinctorus was isolated from Jiangxi Province and cultured in vermiculite and peat. We autoclaved $P$. tinctorius material for one hour at $0.11 \mathrm{MPa}$ pressure and $121^{\circ} \mathrm{C}$ to eliminate any viable Pisolithus tinctorus spores or hyphal fragments in the sterilized material. 
Both inoculated and uninoculated P. massoniana seedlings were grown in natural light under a canopy of transparent film, and watered, as needed, for two years prior to outplanting. In March 2015, 30 inoculated P. massoniana or 30 P. massoniana uninoculated seedlings (with autoclaved inoculum added) were planted in each experimental plot. Seedlings were maintained in our experimental plots for 20 months.

\section{Acidic treatment}

Beneath the constructed canopy, we treated soils in our experimental plots with solutions consisting of either a moderately-acidic $(\mathrm{pH} 4.5)$ solution or a severely-acidic ( $\mathrm{pH} 3.5)$ solution, or an ambient treatment ( $\mathrm{pH}$ 5.6); ambient treatments received solutions under the same constructed canopy. Each experimental treatment plot was replicated three times per treatment combination, totaling 18 experimental plots. To achieve $\mathrm{pH}$ treatment solutions, deionized water was treated with an acidic solution composed of sulfuric acid $\left(\mathrm{H}_{2} \mathrm{SO}_{4}{ }^{2-}\right)$ and nitric acid $\left(\mathrm{HNO}_{3}{ }^{-}\right)$, to lower the $\mathrm{pH}$ of the solution to either $\mathrm{pH} 4.5$ (moderately-acidic) or $\mathrm{pH} 3.5$ (severely-acidic), or for ambient solutions to reach a $\mathrm{pH}$ of 5.6. No additional nutrients were added to our solutions. Each $P$. massoniana seedling, including those in ambient treatments, received $6.7 \mathrm{~L}$ of solution per week, which corresponded to $1.1 \mathrm{~L}$ $\mathrm{m}^{-2}$ per week, for 20 months. Ambient treatments received the same solutions as the severely and moderately-acidic treatments, except the $\mathrm{pH}$ of ambient treatments was 
5.6, which was more basic than the mean annual $\mathrm{pH}$ of precipitation in the region. The mole ratio of $\mathrm{SO}_{4}{ }^{2-}$ to $\mathrm{NO}_{3}{ }^{-}$in the acidic solutions was 4:1. Other ion concentrations in the solutions were $\mathrm{NH}_{4}^{+}-2.67 \mathrm{mg} \mathrm{L}^{-1}, \mathrm{Ca}^{2+}-3.37 \mathrm{mg} \mathrm{L}^{-1}, \mathrm{Mg}^{2+}-0.33 \mathrm{mg} \mathrm{L}{ }^{-1}, \mathrm{Cl}^{-}-14$ $\mathrm{mg} \mathrm{L}^{-1}, \mathrm{~K}^{+}-0.79 \mathrm{mg} \mathrm{L}^{-1}, \mathrm{Na}^{+-} 0.36 \mathrm{mg} \mathrm{L}^{-1}, \mathrm{~F}^{-}-0.39 \mathrm{mg} \mathrm{L}^{-1}$. In addition to spraying treatment solutions on seedlings in experimental plots, plots were consistently watered with local groundwater, $\mathrm{pH} 6.2$, up to several times weekly, as needed, throughout the duration of the experiment to make up for the deficit between the amount of treatment water under the canopy and the ambient rainfall. Amounts applied to plots varied by ambient seasonal precipitation patterns to eliminate drought stress, and did not vary by treatment or plot.

\section{Sample collection}

Plants and soil samples were collected in both November 2015 and November 2016, after 8 and 20 months, respectively. Three randomly selected seedlings were destructively sampled per experimental plot, and plant height, diameter, and fresh weight biomass was recorded from each sample. Plant samples were then oven dried at $60{ }^{\circ} \mathrm{C}$ for $48 \mathrm{~h}$, and weighed on an analytical balance to determine the dry weight biomass. We recorded total plant biomass, aboveground biomass, belowground biomass, and needle weights from each individual, as well as soil properties (SI Table 2-SI Table 3). 
Three soil cores $(20 \mathrm{~cm} \times 3.4 \mathrm{~cm})$ were randomly collected from within the drip line (under the canopy) of treated plants within each plot. Each sample was homogenized and subsequently used to analyze soil properties. Soil subsamples (100 g per subsample) were immediately frozen on dry ice for transport back to the laboratory, and stored at $-80^{\circ} \mathrm{C}$ for molecular analyses of microbial communities. We weighed $0.25 \mathrm{~g}$ aliquots of each frozen soil sample in triplicate to assay for microbial community analyses. Next, we extracted DNA from these soil aliquots and targeted hypervariable portions of both the V3-V4 region of the bacterial 16S rRNA gene and the fungal internal transcribed spacer (fungal ITS1) for Polymerase chain reactions (PCR) amplification. We purified and quantified our PCR products, prior to pooling in equimolar concentrations for Illumina Miseq sequencing (Illumina Incorporated, California; SI Molecular Methods).

\section{Statistical analysis}

To test our hypothesis that plant performance would decline in acidic treated $P$. massoniana_plots, we performed a series of analyses of variance (ANOVAs) with acidic solution treatment as the independent variable and plant height or plant biomass as the dependent variables. To address our second hypothesis, we examined the response of soil organic matter and soil nutrients to acidic treatments by performing response ratios. In each of these cases, the independent variable was acid treatment 
level, and the dependent variable was soil organic matter or soil nutrients. The ratio of the values for each treatment combination was $\log _{2}$-transformed to provide a response factor. To disentangle the direct effects of acid treatments on plants with the indirect effects of acid treatment on mycorrhizal fungi, we measured the effect of Pisolithus inoculation on $P$. massoniana. Where indicated, Tukey post-hoc tests for pairwise comparisons were applied.

We constructed a linear model to address our third and fourth hypotheses that acid treatments would alter the microbial community and Pisolithus inoculation promotes plant, soil, and microbial recovery. For examining microbial and fungal community shifts and to determine the relationship between fungal or microbial community composition and acidic treatments, we used a PERMANOVA analysis of microbial community data using Bray-Curtis dissimilarity and the adonis function in the vegan package of R (Anderson et al. 2008; Oksanen et al. 2012). In this model, we investigated the relationship between fungal and microbial community composition and inoculation in both 2015 and 2016. In order to account for plot to plot variation, we used 'strata' in adonis 2 to restrict permutations solely within our spatial variable (i.e., row proximity to the Jingouba River). We examined how fungal and bacterial community composition shifted in relation to soil nutrients and physicochemical properties, including the ratio of divalent cations to total free $\mathrm{Al}$, by including these environmental variables in our PERMANOVA analyses. 
Principal coordinate analyses (PCoA) plots with Bray-Curtis dissimilarity metrics were used to visualize fungal and bacterial community composition, and to determine whether inoculation was related to microbial community composition or response to acidic treatments. We bioinformatically examined differences in fungal functional groups, trophic levels, and guilds through the use of the FUNguild database (Nguyen et al. 2016) and conducted a series of general linear models to examine shifts in fungal functional groups among our treatment groups. Significant shifts in microbial community composition, increases in soil organic matter, or increased similarity to ambient treatments along with inoculation would suggest that microbial community responses may be related to recovery from the long-term effects of acidification.

\section{Results}

\section{Plant performance}

After two years of treatments, shoot heights and biomass of severely-acid treated plants were lower than untreated plants $(\mathrm{p}<0.05)$ (Table 2). Specifically, we observed that both dried stem biomass and dried needle biomass were significantly lower in plants from severely-acidic treated plots $(\mathrm{p}<0.05)$. Moderately-acidic treatments had no effect on plant growth ( $p>0.05)$. Uninoculated severely-acid treated plants were shorter, had lower stem and needle biomass, and had significantly narrower diameter than uninoculated ambient seedlings ( $\mathrm{p}<0.05$ ). Inoculation with Pisolithus increased plant diameter and dried stem biomass $(\mathrm{p}<0.05)$, but only in the moderately-acidic treatments. 


\section{Soil nutrients}

Soil organic matter content in severely-acid treated plots was significantly lower in uninoculated treatments than in all other treatments $(\mathrm{p}<0.05)$ (Fig 1). However, when severely-acid treated plots were inoculated with Pisolithus, SOM increased to levels equivalent to ambient plots. Although severely-acid treated plots had lower available P, $\mathrm{K}, \mathrm{NH}_{4}-\mathrm{N}$, and $\mathrm{NO}_{3}-\mathrm{N}$ than ambient plots, the inoculated plots treated with severely-acidic treatments had significantly higher $\mathrm{P}, \mathrm{K}, \mathrm{NH}_{4}-\mathrm{N}$, and $\mathrm{NO}_{3}-\mathrm{N}$ than the uninoculated plots treated with the same severely-acidic solution (SI Table 1, Figs 2-4).

\section{Microbial communities}

When controlling for the effect of plot location by restricting our PERMANOVA analyses by proximity to the Jingouba River (our spatial variable) to account for any spatial heterogeneity in our study site, we detected significant main effects of acidic treatment solution and inoculation for fungal communities. We found that variation in fungal communities was determined by acidic treatment solution in both $2015(\mathrm{p}=0.003)$ and $2016(\mathrm{p}<0.001)$, and inoculation in $2015(\mathrm{p}=0.009)$ and 2016 $(\mathrm{p}=0.008)$. Also for fungal communities, we detected significant interactions between $\mathrm{pH}$ of treatment solution and inoculation in $2015(\mathrm{p}=0.017)$ and in $2016(\mathrm{p}<0.001)$. For bacterial communities, we determined that there were significant main effects of acidic treatments in both $2015(\mathrm{p}=0.017)$ and $2016(\mathrm{p}=0.049)$ and Pisolithus inoculation in $2015(\mathrm{p}=0.009)$ and $2016(\mathrm{p}=0.031)$, as well as significant interactions among acidic treatment and inoculation in $2015(\mathrm{p}<0.001)$ and $2016(\mathrm{p}<0.001)$. 
After two years, fungal and microbial communities differed by acidic treatments (Fig 5 and 6), with distinct fungal communities from each treatment combination. Differences in fungal communities were more pronounced in 2016, which represented the longest duration of time, than they were in 2015. The PCoA Axis 2 in both 2015 and 2016 represented $~ 17 \%$ of the variation in fungal communities. PCoA Axis 1 in 2015 represented 51.5\% and Axis 1 in 2016 represented $22.6 \%$ of the variation in fungal communities (Fig 4). No sequences from Pisolithus were detected in any of the treatments with autoclaved Pisolithus added. Fungal communities in Pisolithus inoculated treatments were significantly different than treatment groups with autoclaved Pisolithus added $(\mathrm{p}<0.001)$.

When we evaluated the effects of the ratio of divalent cations $(\mathrm{Ca}+\mathrm{Mg})$ to the total free $\mathrm{Al}$ concentrations on fungal community composition, we found that this

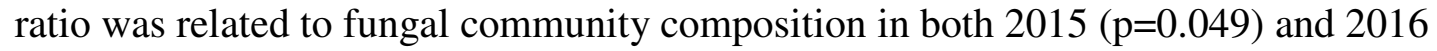
$(p=0.001)$. For bacterial communities, we did not detect any significant effect of the ratio of divalent cations to the total free $\mathrm{Al}$ concentrations in $2015(\mathrm{p}=0.103)$ or for $2016(p=0.1449)$. However, in 2015 we detected a significant interaction between the $\mathrm{pH}$ of the treatment solutions and this ratio on bacterial communities $(\mathrm{p}=0.001)$.

The PCoA Axis 1 in 2015 represented 37.78\% of the variation in bacterial communities, while PCoA Axis 1 in 2016 represented 19.59\%; Axis 2 in 2015 represented $17.07 \%$, and Axis 2 in 2016 represented 10.7\% of the variation in bacterial communities (Fig 5). The most abundant bacterial order was 
Xanthomonadales, followed by Sphingobacteriales. In plots treated with severely-acid solutions, we found a greater relative abundance of Rhodocyclales and Clostridiales within the bacterial communities, as compared to the abundance of those particular orders found in plots treated with more moderate and less acidic treatment solutions. Fungal functional groups varied in our treatment plots. There were greater numbers of fungal pathogens in plots inoculated with Pisolithus, then were found in uninoculated plots $(\mathrm{p}=0.015)$. Additionally, we detected greater saprotrophic fungal richness in plots treated with either moderately-acidic solutions $(\mathrm{p}=0.016)$ or severely-acidic solutions $(\mathrm{p}=0.030)$, than in ambient treatments plots. We found that acidic-solution treatment significantly affected the diversity of mycorrhizal fungal taxa $(\mathrm{p}<0.001)$, as did Pisolithus inoculation $(\mathrm{p}=0.047)$. We detected significant interactions between acidic-solution treatment and inoculation $(\mathrm{p}<0.001)$. We found that the ratio of divalent cations $(\mathrm{Ca}+\mathrm{Mg})$ to total free $\mathrm{Al}$ concentrations affected mycorrhizal fungal community composition ( $\mathrm{p}=0.037$ ), along with significant interactions between $\mathrm{pH}$ and this ratio on mycorrhizal fungal community composition ( $\mathrm{p}=0.006$ ), and a significant interaction among this ratio and Pisolithus inoculation on mycorrhizal communities $(\mathrm{p}=0.049)$.

The ectomycorrhizal taxon Cenococcum was found to dominate severely-acidic treatments inoculated with Pisolithus, and was barely detectable in the moderately-acidic treated or ambient treatments. In fact, Cenococcum was $\sim 200 \mathrm{x}$ more abundant in severely acidic inoculated treatment plants, than in all other 
treatments combined. Some EM fungal taxa, such as Tricholoma were only found in severely-acidic treated plots. While other EM taxa, such as Russula, Sebacina, and Scleroderma were only found in plots treated with moderately-acidic solutions. Another EM taxon, Suillus, was found only in ambient plots, and was not detected in either moderately or severely-acidic treatments. Fungal taxa Amphinema and Archaeorhizomycetes dominated ambient treatment plots, while Trichophaea and Oidiodendron were more prevalent in plots treated with severely-acidic solutions than in other treatment groups.

\section{Discussion and Conclusions}

We examined the effects of long-term acidic treatments and mycorrhizal inoculation on above- and belowground properties in pine plantations in southern China. Overall, we found that severely-acidic treatments not only changed nutrient availability and organic matter content in soils, but also altered bacterial and fungal communities. Plant growth was inhibited and microbial community composition shifted, suggesting that long-term exposure to acidic treatments may affect both above- and belowground components of ecosystems. However, soils from plots inoculated with Pisolithus and exposed to severely-acidic treatments had very different fungal communities than those exposed to acid with autoclaved Pisolithus added. In the context of restoration, the results from these crossed treatments show that Pisolithus inoculation may alter fungal communities. In particular, inoculation 
may have elicited shifts towards fungal communities found in less disturbed soils or sites less impacted by acidic deposition, which may contain fungi that contribute towards stabilizing soil organic matter. Ostensibly, Pisolithus tolerates environmental stress and may either alleviate stressful conditions or prime soil microbial processes (Stroo and Alexander 1984, Silva et al. 2013). Although inoculation may influence the responses of microbes and some abiotic components of these terrestrial ecosystems to acid rain, benefits of Pisolithus inoculation were not evident for plants in severely-acidic treatments. Our findings highlight how biogeochemical cycling by plants and microbes may be constrained by long-term acidic deposition, but that inoculation with plant-associated mycorrhizal fungi may facilitate changes in the community structure of this forested ecosystem.

As terrestrial ecosystems are chronically exposed to acid rain, plants may become malnourished or their productivity may be diminished (Abdulaha-Al Baquy et al. 2017, Likens et al. 1996). Indeed, Pinus massoniana had lower needle biomass and plants were shorter in severely-acid treated plots, as compared to untreated ambient plots. As acidification inhibited plant growth and damaged aboveground tissues, it may have also hindered gas exchange and limited plant $\mathrm{C}$ sequestration (Kemmitt et al. 2006, Janssens et al. 2010, Oulehle et al. 2011). Although inoculation increased plant performance in moderately treated plots more than in ambient plots, inoculation did not significantly promote plant recovery in severely treated plots. 
While the effects on fungal-plant mutualisms may be context-dependent, mycorrhizal associations may be expensive for plants to maintain in stressful environments (Jonsson et al. 2001, Hoeksema et al. 2010). EM fungi often augment plant primary production and plants reallocate a portion of this atmospheric $\mathrm{C}$ to their EM partner for use in building hyphae (Treseder and Holden 2013). However, environmental stress, such as strong acid, may hinder this process and halt both plant and fungal growth.

Pisolithus is a generalist melanized ectomyorrhizal fungus, which has been found to survive in highly acidic environments (Hendrix et al. 1985, Silva et al. 2013). As demonstrated by Fernandez et al. (2013) using minirhizotron imaging, fungal hyphae from another melanized EM fungal taxon, Cenococcum geophilum, may persist in the soil longer than non-melanized ectomycorrhizal fungi, as their melanin-rich hyphae is resistant to decomposition. Given that Cenococcum dominated our severely-acidic Pisolithus inoculated plots, and was barely detectable in any other treatments, the presence and persistence of this taxon may have contributed to our observed patterns of SOM accumulation, if these mycorrhizal residues contributed to soil C stocks (Clemmensen et al. 2013). Therefore, we posit that the prevalence of Cenococcum may have contributed to the marked increases in SOM found in our Pisolithus inoculated, severely-acidic treated plots.

Overall, we found lower SOM, available phosphorus, and nitrate in severely-acidic treated plots, possibly because the acid rain treatments modified the 
existing biogeochemical cycles. Acidic compound treatments may have stimulated microbes to use older and more recalcitrant carbon from soil organic carbon pools, as was found by Waldrop \& Firestone (2004), which could contribute to these relatively low observations of SOM in severely-acidic, but uninoculated, treated plots. While the average acid status of the severely-acidic treated plots did not decrease at the end of the study period, the acidic water solution acidic inputs may have quickly and repeatedly dissolved nutrients from the soil, as was observed by Andersson et al. (2015). Because of its essential role in biomolecules and as a micronutrient, phosphorus is ubiquitous in soil biomass and critical to all living organisms. Fungal diversity has been correlated with higher plant-available phosphorus concentrations (Erlandson et al. 2016). However, since $\mathrm{pH}$ is a strong predictor of changes to fungal community composition, acidic stress could alter the fates of $\mathrm{P}$ during microbially-mediated organic matter turnover. Chemical weathering releases orthophosphate into soil solutions, yet, its bioavailability is optimized at neutral $\mathrm{pH}$ ( $\mathrm{pH} ~ 6.5)$ when $\mathrm{Al}$ and $\mathrm{Ca}$ phosphates are both minimized (Sylvia et al. 2005). Carrino-Kyker et al. (2016) found that elevating $\mathrm{pH}$ also increased soil $\mathrm{P}$ availability, while Barrow (1984) demonstrated P losses and reduced bioavailability at acidic $\mathrm{pH}$ levels.

The impact of acidic conditions on soil microbiota may have caused the variations we observed in nitrate availability. Although nitrate is mobile and readily assimilated by plants and microbes, acidic conditions may constrain the growth and 
activity of nitrifying bacteria (Sylvia et al. 2005). In our study, as the $\mathrm{pH}$ treatments approached neutral, we observed greater nitrate, available $\mathrm{P}$, and SOM, than in severely-acidic treatment plots with autoclaved Pisolithus added. In contrast, we found no response of ammonia to acidification. Given the important role of mycorrhizal fungi in nitrogen cycling and supporting plant $\mathrm{N}$ acquisition, factors that constrain $\mathrm{N}$ cycling bacteria and fungi could influence the productivity of terrestrial ecosystems. Moreover, mycorrhizal fungi are sensitive to $\mathrm{N}$ availability; in an $\mathrm{N}$ deposition gradient in Alaska, Lilleskov et al. (2002) suggest that long-term N deposition dramatically changes ectomycorrhizal community structure and lead to reductions in ectomycorrhizal species richness. When Pisolithus inoculation treatments were applied to these plots treated with severely-acidic solutions, we observed an increase in available P, nitrate, and SOM, which suggests that Pisolithus may be assisting in biogeochemical cycling. Thus, adding a mycorrhizal fungus like Pisolithus may buffer soil conditions to promote nutrient retention, foster conditions conducive to co-existing taxa, or assist in the recovery of soil physicochemical properties in acidic conditions.

\section{Soil microbial communities:}

We found that the direct manipulations of simulated rain acidity extended beyond the plant community to affect soil microbes. Pisolithus inoculation significantly altered fungal and bacterial community composition. Further, the 
interactive effect of acidic treatment and inoculation status altered belowground fungal communities in a way that differed from the separate impact of each treatment. Clemmenson (2015) showed that mycorrhizal functional types may strongly, and differentially, influence $\mathrm{N}$ immobilization and $\mathrm{C}$ sequestration in forested ecosystems. Therefore, the functional response of fungal communities to mycorrhizal inoculation may feedback to alter nutrient cycling or microbial interactions in ecosystems exposed to chronic acidic deposition. These findings highlight the potential of Pisolithus inoculum to buffer soil conditions for other fungi in ecosystems exposed to long-term acidic deposits.

Our study provides evidence that both acidic treatments and Pisolithus inoculation affect aboveground and belowground components of ecosystems, as well as soil physicochemical properties, yet it has some limitations. For instance, our study was conducted within pine plantations in southern China, and thus our interpretations are limited to Pinus massoniana forested ecosystems and plantations in this region. Additionally, although we applied acidic treatments to soils in our treatment plots weekly for 20 months, at the end of our study soil $\mathrm{pH}$ did not vary predictably across treatments. In fact, soil pH was as low in the acidic Pisolithus inoculated plots as it was in ambient plots with autoclaved Pisolithus added. Therefore, protracted additions of different levels of acidic solutions may have influenced the plant and microbial cycling of nutrients and water differently, which may have altered soil $\mathrm{pH}$ differently in our inoculated treatment plots, potentially because of stress-response 
traits associated with Pisolithus. Indeed, other studies have shown this fungus to be resilient and facilitate the recovery of plants grown in acidic coal spoils (Marx and Artman 1979).

It is worth noting that there was some inter-annual and plot-to-plot variation in soil $\mathrm{pH}$, which in 2016, was significantly correlated with distance from the river. This may in turn have contributed to some of the effects and patterns observed in soil physicochemical properties or microbial communities throughout the study. However, we included distance from river as a factor in our statistical analyses, and did not detect effects of distance from river on initial soil $\mathrm{pH}$ or in 2015 , and we have statistically proven differences driven by acidic-solution treatment and inoculation with Pisolithus.

Additionally, we attempted to prevent drought stress by applying additional water throughout the study. However, as the water used in between treatments had a normal $\mathrm{pH}$ for groundwater in the region (6.2), this may have contributed to the fact that the soil throughout the study did not show consistent acidifying effects of treatment, despite clear plant and microbial responses to the severely acidic treatment. Yet, weekly application of acidic solution treatments was applied for almost two years, which we found to affect both biotic communities and soil physicochemical properties. Overall, results from our acidic-solution treatments and inoculation manipulation suggest that Pisolithus inoculation may play a role in the remediation of forested ecosystems though facilitating changes to the mycorrhizal and microbial 
community, which could increase inputs into soil organic matter pools in chronically exposed severely-acidic ecosystems.

Our results provide evidence that soil abiotic and biotic components may be negatively affected by human-practices that increase acidic deposition, acid rain in particular. We found less SOM in severely-acidic treated plots; SOM, as illustrated by Magdoff and Weil (2004), may influence soil aggregate stability or improve plant growth. Pisolithus inoculation promoted both soil abiotic and fungal community recovery in severely-acidic treatment plots. Fungal community assembly in Pisolithus inoculated plots may include taxa which more efficiently use soil resources or are more effective at nutrient transfer to their plant hosts. However, severely-acidic inputs may damage aboveground vegetation and inhibit productivity, limiting $\mathrm{C}$ allocation to their associated EM partners. The resultant unequal bi-directional exchange of resources could feedback to promote fungal hyphal sloughing and the accumulation of C-rich fungal residues, which may contribute to our observed increases in soil organic matter in the Pisolithus inoculated severely-acidic treatment plots. As acidification directly reduces plant performance, it may also indirectly inhibit EM fungal proliferation.

Altogether, our findings suggest that chronic exposure to acidic inputs may change plant and soil properties and fungal and bacterial communities in exposed forested ecosystems. Moreover, inoculation with Pisolithus may assist in the recovery of some components of belowground ecosystems. These data have implications for 
management of acid rain-exposed forested ecosystems. For instance, restoration

methods that aim to restore soil microbial communities, such as Pisolithus

inoculation, may be especially effective at improving the soil nutrients and soil

organic content at such acidified sites. This study underscores the importance of both

reducing acidification in rain systems and maintaining soil microbial communities

when restoring chronically exposed ecosystems.

\section{Acknowledgements}

This research was supported by the Public Welfare Project of the National Scientific

Research Institution (CAFRIFEEP201402) in China. We thank D. Jackson, G. Logan,

B. Pickett, S. Saroa, M. Phillips, and A. Swanson for intellectual feedback and

insightful comments on previous drafts. Moreover, we thank the Center for

Conservation Biology and M.F. Allen and E.B. Allen for hosting ZC and MM. We are grateful for mycorrhizal fungal inoculum and inoculation support from the Study

Center of Tree Mycorrhizae, from the Chinese Academy of Forestry. ZC was supported by the Public Welfare Project of the National Scientific Research Institution

(CAFYBB2017SY026). EA, MM and KA were supported by the United States National Science Foundation (NSF ICER-1541047), EA was further supported by the National Science Foundation (NSF BIO-EF-1550920), and MM was supported by funding from the Mycological Society of America's Translational Mycology Postdoctoral Award. 


\section{References}

Abdulaha-Al Baquy, M., J.Y. Li, C.Y. Xu, K. Mehmood and R.K. Xu. 2017.

Determination of critical $\mathrm{pH}$ and $\mathrm{Al}$ concentration of acidic Ultisols for wheat and canola crops. Solid Earth 8: 149-159. doi:10.5194/se-8-149-2017.

Allen, E.B., L.M. Egerton-Warburton, B.E. Hilbig and J.M. Valliere. 2016. Interactions of arbuscular mycorrhizal fungi, critical loads of nitrogen deposition, and shifts from native to invasive species in a southern California shrubland. Botany 94: 425-433. doi:10.1139/cjb-2015-0266.

Anderson, M. J., Gorley, R. N., \& Clarke, R. K. (2008). Permanova+ for Primer: Guide to Software and Statistical Methods.

Anderson, T.H. and K.H. Domsch. 1993. The metabolic quotient for $\mathrm{CO}_{2}\left(\mathrm{QCO}_{2}\right)$ as a specific activity parameter to assess the effects of environmental-conditions, such as $\mathrm{pH}$, on the microbial biomass of forest soils. Soil Biol Biochem 25: 393-395. doi:Doi 10.1016/0038-0717(93)90140-7.

Andersson, K.O., M.K. Tighe, C.N. Guppy, P.J. Milham and T.I. McLaren. 2015. Incremental acidification reveals phosphorus release dynamics in alkaline vertic soils. Geoderma 259: 35-44. doi:10.1016/j.geoderma.2015.05.001.

Averill, C. and B. Waring. 2017. Nitrogen limitation of decomposition and decay: how can it occur? Global Change Biology.

Arnolds, E. 1988. The changing macromycete flora in the Netherlands. T Brit Mycol Soc 90: 391-406.

Bååth E. and K. Arnebrandt. 1994. Growth-rate and response of bacterial communities to $\mathrm{pH}$ in limed and ash treated forest soils. Soil Biology and Biochemistry 26: 995-1001.

Baldrian, P., M. Kolař́k, M. Štursová, J. Kopecký, V. Valášková, T. Větrovský, et al. 2012. Active and total microbial communities in forest soil are largely different and highly stratified during decomposition. The ISME journal 6: 248.

Bardhan, S., S. Jose and M.A. Jenkins. 2012. Microbial community diversity and composition across a gradient of soil acidity in spruce-fir forests of the southern Appalachian Mountains. Appl Soil Ecol 61: 60-68.

Baroglio C., F. Bosco and V. Specchia. 1999. Biomass production of the mycorrhizal fungus Suillus grevillei: effect of $\mathrm{pH}$ and ammonium. Microbios 103: 163-177.

Barrow, N.J. 1984. Modeling the effects of $\mathrm{pH}$ on phosphate sorption by soils. J Soil Sci 35: 283-297.

Berger, T.W., S. Turtscher, P. Berger and L. Lindebner. 2016. A slight recovery of soils from Acid Rain over the last three decades is not reflected in the macro nutrition of 
beech (Fagus sylvatica) at 97 forest stands of the Vienna Woods. Environ Pollut 216: 624-635. doi:10.1016/j.envpol.2016.06.024.

Bobbink, R., K. Hicks, J. Galloway, T. Spranger, R. Alkemade, M. Ashmore, et al. 2010. Global assessment of nitrogen deposition effects on terrestrial plant diversity: a synthesis. Ecol Appl 20: 30-59. doi: 10.1890/08-1140.1.

Bodeker, I.T.M., C.M.R. Nygren, A.F.S. Taylor, A. Olson and B.D. Lindahl. 2009. Class II peroxidase-encoding genes are present in a phylogenetically wide range of ectomycorrhizal fungi. Isme J 3: 1387-1395. doi:10.1038/ismej.2009.77.

Burnham M B, Cumming J R, Adams M B, et al. Soluble soil aluminum alters the relative uptake of mineral nitrogen forms by six mature temperate broadleaf tree species: possible implications for watershed nitrate retention. Oecologia, 2017, 185(3):1-11.

Carrino-Kyker, S.R., L.A. Kluber, S.M. Petersen, K.P. Coyle, C.R. Hewins, J.L. DeForest, et al. 2016. Mycorrhizal fungal communities respond to experimental elevation of soil $\mathrm{pH}$ and $\mathrm{P}$ availability in temperate hardwood forests. Fems Microbiol Ecol 92. doi:ARTN fiw02410.1093/femsec/fiw024.

Chen, D.M., J.J. Li, Z.C. Lan, S.J. Hu and Y.F. Bai. 2016. Soil acidification exerts a greater control on soil respiration than soil nitrogen availability in grasslands subjected to long-term nitrogen enrichment. Funct Ecol 30: 658-669. doi:10.1111/1365-2435.12525.

Chen, Z. and H. Shang. 2014. Effects of ectomycorrhizal fungi on nutrient elements of Pinus massoniana seedlings under simulated acid rain. Scientia Silvae Sinicae 50: 156-163.

Chen, Z., L. Wang and H. Shang. 2013. Effects of ectomycorrhizal fungi (Pisolithus tinctorius (Pers., Coker \& Couch) on the biomass of masson pine (Pinus massoniana) seedlings under simulated acid rain. Acta Ecologica Sinica 33: 6526-6533.

Chorianopoulou, S.N., Y.I. Saridis, M. Dimou, P. Katinakis and D.L. Bouranis. 2015. Arbuscular mycorrhizal symbiosis alters the expression patterns of three key iron homeostasis genes, ZmNAS1, ZmNAS3, and ZmYS1, in S deprived maize plants. Frontiers in plant science 6 .

Chuyong, G., D. Newbery and N. Songwe. 2000. Litter nutrients and retranslocation in a central African rain forest dominated by ectomycorrhizal trees. New Phytol 148: 493-510.

Clemmensen, K.E., A. Bahr, O. Ovaskainen, A. Dahlberg, A. Ekblad, H. Wallander, et al. 2013. Roots and associated fungi drive long-term carbon sequestration in boreal forest. Science 339: 1615-1618. doi:10.1126/science.1231923. 
Clemmensen, K.E., R.D. Finlay, A. Dahlberg, J. Stenlid, D.A. Wardle and B.D. Lindahl. 2015. Carbon sequestration is related to mycorrhizal fungal community shifts during long-term succession in boreal forests. New Phytol 205: 1525-1536. doi:10.1111/nph.13208.

Courty, P.E., A. Franc and J. Garbaye. 2010a. Temporal and functional pattern of secreted enzyme activities in an ectomycorrhizal community. Soil Biol Biochem 42: 2022-2025. doi:10.1016/j.soilbio.2010.07.014.

Courty, P.E., K. Pritsch, M. Schloter, A. Hartmann and J. Garbaye. 2005. Activity profiling of ectomycorrhiza communities in two forest soils using multiple enzymatic tests. New Phytol 167: 309-319. doi:10.1111/j.1469-8137.2005.01401.x.

Dighton, J. and A.E. Jansen. 1991. Atmospheric pollutants and ectomycorrhizae - More questions than answers. Environ Pollut 73: 179-204. doi: 10.1016/0269-7491(91)90049-3.

Dighton, J. and R.A. Skeffington. 1987. Effects of artificial acid precipitation on the mycorrhizas of scots pine-seedlings. New Phytol 107: 191-202. doi:DOI 10.1111/j.1469-8137.1987.tb04893.x.

Erlandson, S.R., J.A. Savage, J.M. Cavender-Bares and K.G. Peay. 2016. Soil moisture and chemistry influence diversity of ectomycorrhizal fungal communities associating with willow along an hydrologic gradient. Fems Microbiol Ecol 92. doi:ARTN fiv14810.1093/femsec/fiv148.

Fan, H.B. and Y.H. Wang. 2000. Effects of simulated acid rain on germination, foliar damage, chlorophyll contents and seedling growth of five hardwood species growing in China. Forest Ecol Manag 126: 321-329.

Fellner, R. and V. Pešková. 1995. Effects of industrial pollutants on ectomycorrhizal relationships in temperate forests. Can J Bot 73: S1310-S1315.

Feng, Z.W. 1993. Effects of acid rain on ecosystem. China Science and Technology Press.

Fernandez, C.W., L. McCormack, J.M. Hill, S.G. Pritchard, R.T. Koide. 2013. On the persistence of Cenocossum geophilum ectomycorrhizas and its implications for forest carbon and nutrient cycles. Soil Biology and Biochemistry. 65: 141-143.

Ferreira V, Guérold F. Leaf litter decomposition as a bioassessment tool of acidification effects in streams: Evidence from a field study and meta-analysis. Ecological Indicators, 2017, 79:382-390.

Fierer, N. and R.B. Jackson. 2006. The diversity and biogeography of soil bacterial communities. P Natl Acad Sci USA 103: 626-631. 
Glassman, S.I., I.J. Wang and T.D. Bruns. 2017. Environmental filtering by $\mathrm{pH}$ and soil nutrients drives community assembly in fungi at fine spatial scales. Molecular Ecology: 1-14. doi: 10.1111/mec.14414

Griffiths, R.I., B.C. Thomson, P. James, T. Bell, M. Bailey and A.S. Whiteley. 2011. The bacterial biogeography of British soils. Environ Microbiol 13: 1642-1654. doi:10.1111/j.1462-2920.2011.02480.x.

Hendrix, JW, CS Hunt and DM Maronek. 1985. Relationship between the ectomycorrhizal fungus Pisolithus tinctorius associated with Loblolly Pine and acid-generating Thiobacillus spp on an acidic strip mine site. Canadian Journal of Microbiology 3: 878-879.

Hoeksema, J.D., V.B. Chaudhary, C.A. Gehring, N.C. Johnson, J. Karst, R.T. Koide, A. Pringle, C. Zabinski, J.D. Bever, J .C. Moore, G.W.T. Wilson, J.N. Klironomos, J. Umbanhower. 2010. A meta-analysis of context-dependency in plant response to inoculation with mycorrhizal fungi. Ecology Letters. 13: 394-407

Jandl, R., S. Smidt, F. Mutsch, A. Furst, H. Zechmeister, H. Bauer, et al. 2012. Acidification and Nitrogen Eutrophication of Austrian Forest Soils. Applied \& Environmental Soil Science. 2012.

Janssens, I., W. Dieleman, S. Luyssaert, J.-A. Subke, M. Reichstein, R. Ceulemans, et al. 2010. Reduction of forest soil respiration in response to nitrogen deposition. Nature geoscience.-London, 2008, currens 3: 315-322.

Jonsson, L.M., M.C. Nilsson, D.A. Wardle and O. Zackrisson. 2001. Context dependent effects of ectomycorrhizal species richness on tree seedling productivity. Oikos 93: 353-364. doi:DOI 10.1034/j.1600-0706.2001.930301.x.

Jones, R.T., M.S. Robeson, C.L. Lauber, M. Hamady, R. Knight and N. Fierer. 2009. A comprehensive survey of soil acidobacterial diversity using pyrosequencing and clone library analyses. ISME J 3: 442-453. doi:10.1038/ismej.2008.127.

Kemmitt, S.J., D. Wright, K.W. Goulding and D.L. Jones. 2006. pH regulation of carbon and nitrogen dynamics in two agricultural soils. Soil Biology and Biochemistry 38: 898-911.

Kluber, L.A., S.R. Carrino-Kyker, K.P. Coyle, J.L. DeForest, C.R. Hewins, A.N. Shaw, et al. 2012. Mycorrhizal response to experimental $\mathrm{pH}$ and $\mathrm{P}$ manipulation in acidic hardwood forests. Plos One 7. doi:ARTN e4894610.1371/journal.pone.0048946.

Landesman, W.J., D.M. Nelson and M.C. Fitzpatrick. 2014. Soil properties and tree species drive beta-diversity of soil bacterial communities. Soil Biol Biochem 76: 201-209. doi:10.1016/j.soilbio.2014.05.025. 
Lauber, C.L., M. Hamady, R. Knight and N. Fierer. 2009. Pyrosequencing-based assessment of soil $\mathrm{pH}$ as a predictor of soil bacterial community structure at the continental scale. Appl Environ Microb 75: 5111-5120. doi:10.1128/Aem.00335-09.

Leake J R. Is diversity of ectomycorrhizal fungi important for ecosystem function? New Phytologist, 2001, 152(1):1-3.

Lewontin, R.C. 1969. Meaning of stability. Brookhaven Symposium of Biology. 13. Leys, B.A., G.E. Likens, C.E. Johnson, J.M. Craine, B. Lacroix and K.K. McLauchlan. 2016. Natural and anthropogenic drivers of calcium depletion in a northern forest during the last millennium P Natl Acad Sci USA 113:6934. doi:10.1073/pnas.1611402113.

Liang, Y. and Z. Liu. 1999. Effect of aluminum-resistant fungus ALF-1 (Neurospora sp.) from tea rhizospheric soil on $\mathrm{pH}$ value of acidic soil. Journal of Tea Science 19: $115-118$.

Likens, G.E., C.T. Driscoll and D.C. Buso. 1996. Long-term effects of acid rain: Response and recovery of a forest ecosystem. Science 272: 244-246.

Lilleskov, E.A., T.J. Fahey, T.R. Horton, and G.M. Lovett. 2002. Ecology. 83: 104-115 Liu, X., L. Duan, J. Mo, E. Du, J. Shen, X. Lu, et al. 2011. Nitrogen deposition and its ecological impact in China: An overview. Environ Pollut 159: 2251-2264.

Lv, Y., C. Wang, Y. Jia, W. Wang, X. Ma, J. Du, et al. 2014. Effects of sulfuric, nitric, and mixed acid rain on litter decomposition, soil microbial biomass, and enzyme activities in subtropical forests of China. Appl Soil Ecol 79: 1-9.

Macaulay B M, Abigael T O. Effects of simulated acid rain on the morphology, phenology and yield of Okra (Abelmoschus esculentus (L.) Moench). Journal of Environmental Science Computer Science \& Engineering \& Technology, 2015, 4(2):501-508.

Mack, M.C., E.A.G. Schuur, M.S. Bret-Harte, G.R. Shaver and F.S. Chapin. 2004. Ecosystem carbon storage in arctic tundra reduced by long-term nutrient fertilization. Nature 431: 440-443. doi:10.1038/nature02887.

Magdoff, F and R Weil. 2004. Soil Organic Matter in Sustainable Agriculture. CRC Press, Boca Raton, Florida.

Markkola, A.M. and R. Ohtonen. 1988. The effects of acid deposition on fungi in forest humus. In: Ectomycorrhiza and Acid Rain. Ed: A.E. Jansen, J. Dighton, and A.H.M. Bresser. 122-126. Bilthoven. The Netherlands: CEC.

Marx, D. H., and J. D. Artman. 1979. Pisolithus tinctorius ectomycorrhizae improve survival and growth of pine seedlings on acid coal spoils in Kentucky and Virginia. Reclamation Review 2:23-31. 
McNear Jr., D.H. 2013. The rhizosphere-roots, soil and everything in between. Nature Education Knowledge 4:1.

Molina, R. and J.M. Trappe. 1982. Patterns of ectomycorrhizal host specificity and potential among Pacific Northwest conifers and fungi. Forest Sci 28: 423-458.

Nara, K., H. Nakaya, B. Wu, Z. Zhou and T. Hogetsu. 2003. Underground primary succession of ectomycorrhizal fungi in a volcanic desert on Mount Fuji. New Phytol 159: 743-756.

Nguyen, N.H., Z. Song, S.T. Bates, S.M. Branco, L. Tedersoo, J. Menke, J.S. Schilling, P. Kennedy. FUNGuild: An open annotation tool for parsing fungal community datasets by ecological guilds. Fungal Ecology. 20: 241-248

Odiyi, B.O. and J.F. Bamidele 2013 Effect of simulated acid rain on the growth and yield of cassava Manihot esculenta (Crantz). Journal of Agricultural Sciences. 6: 97-101.

Oksanen J., Blanchet F.G., Kindt R., Legendre P., Minchin P.R., O'Hara R.B., Simpson G.L., Solymos P., Stevens M.H.H., Wagner H. (2012) vegan: Community Ecology Package. R package version 2.0-3.

Oulehle, F., C.D. Evans, J. Hofmeister, R. Krejci, K. Tahovska, T. Persson, et al. 2011. Major changes in forest carbon and nitrogen cycling caused by declining sulphur deposition. Global Change Biol 17: 3115-3129.

Percent, S.F., M.E. Frischer, P.A. Vescio, E.B. Duffy, V. Milano, M. McLellan, et al. 2008. Bacterial community structure of acid-impacted lakes: What controls diversity? Appl Environ Microb 74: 1856-1868. doi:10.1128/Aem.01719-07.

Prewitt, L., Y. Kang, M.L. Kakumanu and M. Williams. 2014. Fungal and bacterial community succession differs for three wood types during decay in a forest soil. Microbial Ecol 68: 212-221.

Qu, L., K. Makoto, D. Choi, A. Quoreshi and T. Koike. 2010. The role of ectomycorrhiza in boreal forest ecosystem. Permafrost Ecosystems. Springer. 413-425.

Raschke, K. 1975. Stomatal action. Annual Reviews of Plant Physiology 26: 309-340

Reininger, D., P. Fiala and T. Samek. 2011. Acidification of forest soils in the Hrubý Jeseník region. Soil \& Water Research.

Rousk, J., E. Baath, P.C. Brookes, C.L. Lauber, C. Lozupone, J.G. Caporaso, et al. 2010. Soil bacterial and fungal communities across a pH gradient in an arable soil. Isme J 4: 1340-1351. doi:10.1038/ismej.2010.58.

Rustad, L.E., I.J. Fernandez, M.B. David, M.J. Mitchell, K.J. Nadelhoffer and R.B. Fuller. 1996. Experimental soil acidification and recovery at the Bear Brook Watershed in Maine. Soil Science Society of America Journal 60: 1933-1943. 
Silva, R.F. M. Lupatini, L. Trindade, Z.I. Antoniolli, R.B. Steffen and R. Andreazza. 2013. Copper resistence of different ectomycorrhizal fungi such as Pisolithus microcarpus, Pisolithus sp., Scleroderma sp., and Suillus sp. Brazillian Journal of Microbiology. 44: 619-627.

Sobotka, A. 1964. Effects of industrial exhalations on soil biologies of Norway spruce stands in the Ore mountains. Lesnicky Casopsis 37: 987-1002.

Stroo, H.F. and M. Alexander. 1985. Effect of simulated acid-rain on mycorrhizal infection of Pinus-Strobus L. Water Air Soil Poll 25: 107-114. doi: 10.1007/Bf00159629.

Sylvia, D.M., P.G. Hartel, J.J. Fuhrmann and D.A. Zuberer. 2005. Principles and Applications of Soil Microbiology. Second ed. Pearson, Upper Saddle River, New Jersey.

Talbot, J.M., F. Martin, A. Kohler, B. Henrissat and K.G. Peay. 2015. Functional guild classification predicts the enzymatic role of fungi in litter and soil biogeochemistry. Soil Biol Biochem 88: 441-456. doi:10.1016/j.soilbio.2015.05.006.

Tonneijck F H, Jansen B, Kgj N, et al. Towards understanding of carbon stocks and stabilization in volcanic ash soils in natural Andean ecosystems of northern Ecuador. European Journal of Soil Science, 2010, 61(3):392-405.

Treseder, K.K. and M.F. Allen. 2000. Mycorrhizal fungi have a potential role in soil carbon storage under elevated $\mathrm{CO}_{2}$ and nitrogen deposition. New Phytol 147: 189-200. doi:DOI 10.1046/j.1469-8137.2000.00690.x.

Treseder, K.K. and S.R. Holden. 2013. Fungal carbon sequestration. Science 339: 1528-1529.

Türtscher, S., P. Berger, L. Lindebner and T.W. Berger. 2017. Declining atmospheric deposition of heavy metals over the last three decades is reflected in soil and foliage of 97 beech (Fagus sylvatica) stands in the Vienna Woods. Environ Pollut 230: 561-573. doi:10.1016/j.envpol.2017.06.080.

van der Heijden, M.G.A., R.D. Bardgett and N.M. van Straalen. 2008. The unseen majority: soil microbes as drivers of plant diversity and productivity in terrestrial ecosystems. Ecol Lett 11: 296-310. doi:10.1111/j.1461-0248.2007.01139.x.

Virant-Klun, I. and N. Gogala. 1995. Impact of VAM on phosphorus nutrition of maize with low soluble phosphate fertilization. Journal of Plant Nutrition 18: $1815-1823$.

Waldrop, M.P. and M.K. Firestone. 2004. Altered utilization patterns of young and old soil $\mathrm{C}$ by microorganisms caused by temperature shifts and $\mathrm{N}$ additions. Biogeochemistry 67: 235-248. doi:Doi 10.1023/B:Biog.0000015321.51462.41. 
Wallenda, T. and I. Kottke. 1998. Nitrogen deposition and ectomycorrhizas. New Phytol 139: 169-187. doi: 10.1046/j.1469-8137.1998.00176.x.

Wang, D.Z., X. Jiang, W. Rao and J.Z. He. 2009. Kinetics of soil cadmium desorption under simulated acid rain. Ecological Complexity 6: 432-437.

Yang, Y., C. Ji, W. Ma, S. Wang, S. Wang, W. Han, et al. 2012. Significant soil acidification across northern China's grasslands during 1980s-2000s. Global Change Biol 18: 2292-2300.

Yu H, Chen Z., Shang H., Cao J.X. 2017. Effects of ectomycorrhizal fungi on seedlings of Pinus massoniana under simulated acid rain. Acta Ecologica Sinica. 37( 16) 5418- 5427.

Zieger, E. Biology of stomatal guard cells. Annual reviews of plant physiology. 34: $441-475$

Zhang, J.E., Y. Ouyang and D.J. Ling. 2007. Impacts of simulated acid rain on cation leaching from the Latosol in south China. Chemosphere 67: 2131-2137.

Zhang, X., H. Jiang, J. Jin, X. Xu and Q. Zhang. 2012. Analysis of acid rain patterns in northeastern China using a decision tree method. Atmospheric Environment 46: 590-596.

Zhao, Y., L. Duan, J. Xing, T. Larssen, C.P. Nielsen and J. Hao. 2009. Soil acidification in China: is controlling $\mathrm{SO}_{2}$ emissions enough? American Chemical Society. 


\section{List of Tables:}

Table 1. Acidic solution and soil $\mathrm{pH}$ across time and among treatment combinations.

Table 2. Pinus massoniana properties in response to inoculation and acidic treatments. 


\section{List of Figures:}

Figure 1. Map of the study system with scale bar.

Figure 2. Response of soil organic matter to acidic treatments and Pisolithus inoculation.

Figure 3. Response of nitrate to acidic treatments and Pisolithus inoculation.

Figure 4. Response of available phosphorus to acidic treatments and Pisolithus inoculation.

Figure 5. Principal coordinate analyses of fungal communities

Figure 6. Principal coordinate analyses of bacterial communities

\section{Figure legends}

Fig 1. Map of the study system with scale bar. Location of our experimental plots within the Changsha County, Hunan Province (N28 26'9.13" E113¹1'39.26"). Acidic treatment solutions are colored in black for severely acidic treatment, blue for moderately acidic treatment, and green for ambient treatment. Treatment plots inoculated with Pisolithus tinctorius have patterned fill, while uninoculated treatments have solid fill. Black outline denotes footprint of covered canopy, yellow borders indicate row from Jingouba River, as a spatial delimiter within the study system. Inset map of China indicates where the experimental plots are located geographically.

\section{Fig 2. Response of soil organic matter to acidic treatments and Pisolithus}

inoculation. Response of organic matter content in $\mathrm{g} \mathrm{kg}^{-1}$ of soil to acid and Pisolithus inoculation treatments, as compared to the organic matter content of uninoculated ambient plots. Responses $\log _{2}$ transformed, thus each unit on the horizontal $\mathrm{x}$-axis represents a two-fold change. Error bars correspond to $95 \%$ confidence intervals of the 
mean. If points and error bars cross the dashed line at 0.0 , it indicates that the particular treatment is statistically equivalent to the ambient. If points and error bars are completely below 0.0 that indicates that soil organic matter is significantly less than (left of) the untreated ambient plots; if points and error bars are completely above (to the right of) 0.0 , that would indicates that soil organic matter significantly increased in that particular treatment, as compared to untreated ambient plots.

\section{Fig 3. Response of nitrate to acidic treatments and Pisolithus inoculation.}

Response of nitrate in $\mathrm{mg} / \mathrm{kg}$ of soil to acid and Pisolithus inoculation treatments, as compared to the organic matter content of uninoculated untreated ambient plots. Responses $\log _{2}$ transformed, thus each unit on the horizontal $\mathrm{x}$-axis represents a two-fold change. Error bars correspond to $95 \%$ confidence intervals of the mean. If points and error bars cross the dashed line at 0.0 , it indicates that the particular treatment is statistically equivalent to the ambient. If points and error bars are completely below 0.0 that indicates that soil nitrate $\left(\mathrm{mg} \mathrm{kg}^{-1}\right)$ is significantly less than (left of) the untreated ambient; if points and error bars are completely above (to the right of) 0.0 , that would indicates that soil nitrate significantly increased in that treatment, as compared to untreated ambient plots.

\section{Fig 4. Response of available phosphorus to acidic treatments and Pisolithus}

inoculation. Response of available phosphorus $\left(\mathrm{mg} \mathrm{kg}^{-1}\right)$ to acid and mycorrhizal inoculation treatments, as compared to the available phosphorus in uninoculated ambient plots. Responses $\log _{2}$ transformed, thus each unit on the horizontal $\mathrm{x}$-axis represents a two-fold change. Error bars correspond to $95 \%$ confidence intervals of the mean. If points and error bars cross the dashed line at 0.0 , it indicates that the particular treatment is statistically equivalent to the ambient. If points and error bars are completely below 0.0 that indicates that available phosphorus is significantly less than (left of) the untreated ambient; if points and error bars are completely above (to the right of) 0.0 , that would indicates that available phosphorus significantly increased in that particular treatment, as compared to untreated ambient plots.

Fig 5. Principal coordinate analyses of fungal communities. Principal coordinate analysis (PCoA) plot of fungal ITS1 sequencing results from 2015 (a) and 2016 (b), showing fungal community responses to acid and Pisolithus inoculation treatments. 
Solid shapes indicated inoculation with Pisolithus; open shapes indicate uninoculated treatments.

Fig 6. Principal coordinate analyses of bacterial communities. Principal coordinate analysis (PCoA) plot of 16S sequencing results from both 2015 (a) and 2016 (b), showing bacterial and archaeal community responses to acid and inoculation treatments. Solid shapes represent inoculation with Pisolithus tinctorius; open shapes indicate uninoculated treatments. 


\section{Supplemental information}

Supplemental Table 1. Spatial heterogeneity in our experimental site: $\mathrm{pH}$ shifts with row from Jingouba River.

Supplemental Table 2. Soil nutrients and soil organic matter in both 2015 and 2016 in our plots treated with acidic treatments and inoculated with Pisolithus.

Supplemental Table 3. Soil physicochemical properties and elemental analyses from soil collected in 2015 from our plots treated with acidic treatments and inoculated with Pisolithus.

Supplemental Table 4. Bacterial community diversity metrics.

Supplemental Table 5. Fungal community diversity metrics.

\section{Supplemental Figure 1. Non-metric multi-dimensional scaling plot illustrating} differences in key fungal taxa by acidic-solution treatment. Shapes represent a portion of the fungal community from either severely acidic treatment plots (circles) shown surrounded by blue dashed ellipse, moderately acidic treatments (squares) shown by the green dashed ellipse, or ambient treatments (triangles) represented by the orange solid ellipse. Ectomycorrhizal fungal taxa (e.g., Suillus) and putative root endophytes (e.g., Archaeorhizomycetes) associated with particular acidic treatment categories are shown in text in close proximity to that representative ellipse.

Supplemental Figure 2. Fungal taxa plotted in bar charts, shown with the relative abundance of fungal taxa by acidic-solution treatment and by Pisolithus inoculation; treatments with autoclaved Pisolithus added marked as 'Non-inoculated.'

Supplemental Figure 3. Bacterial taxa plotted in bar charts, shown with the relative abundance of fungal taxa by acidic-solution treatment and by Pisolithus inoculation; treatments with autoclaved Pisolithus added marked as 'Non-inoculated.'

Supplemental Methods: Molecular methods used on our soil microbial analyses. 
Figure 1. Map of study location

Click here to download high resolution image

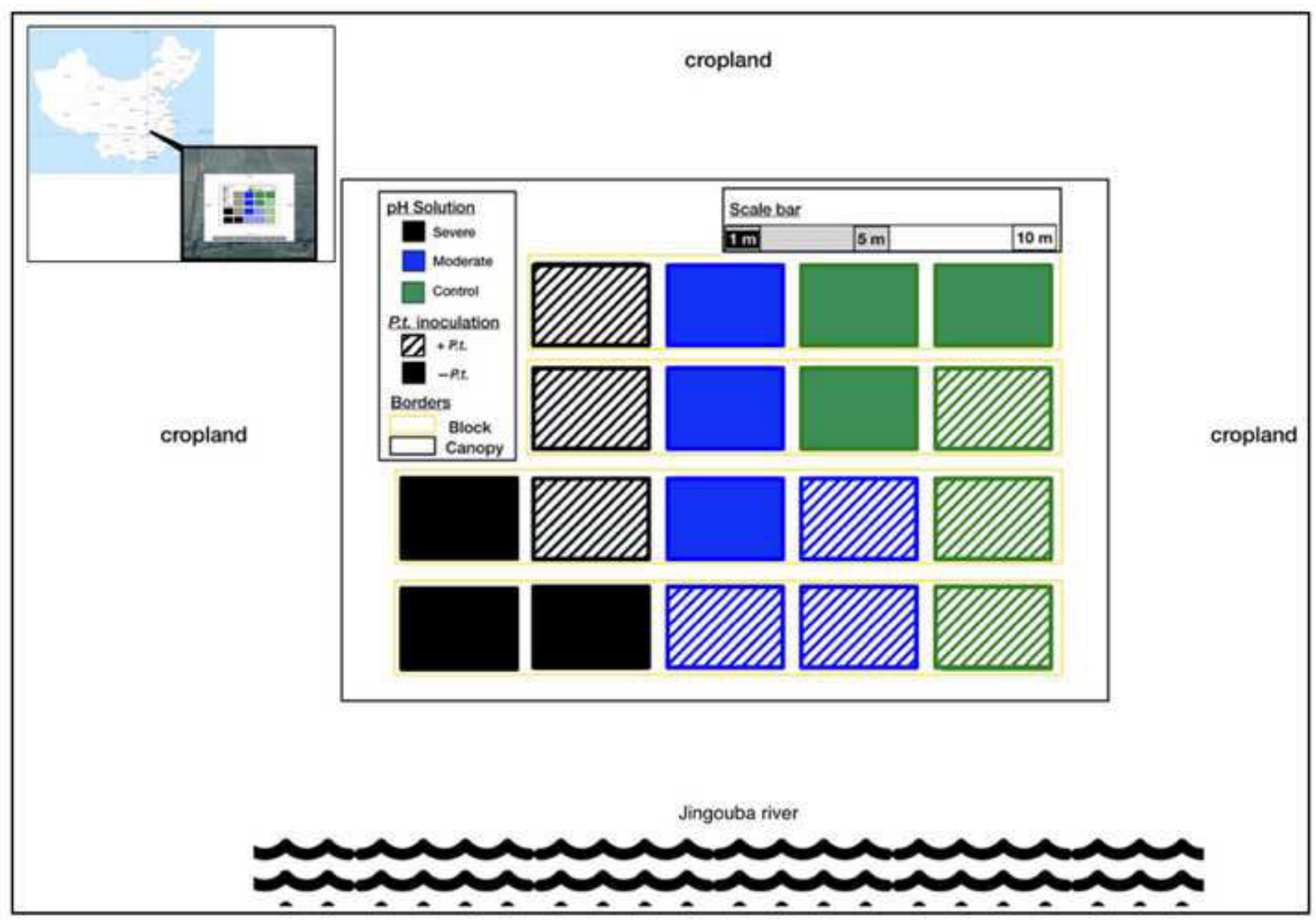

cropland

Jingouba river

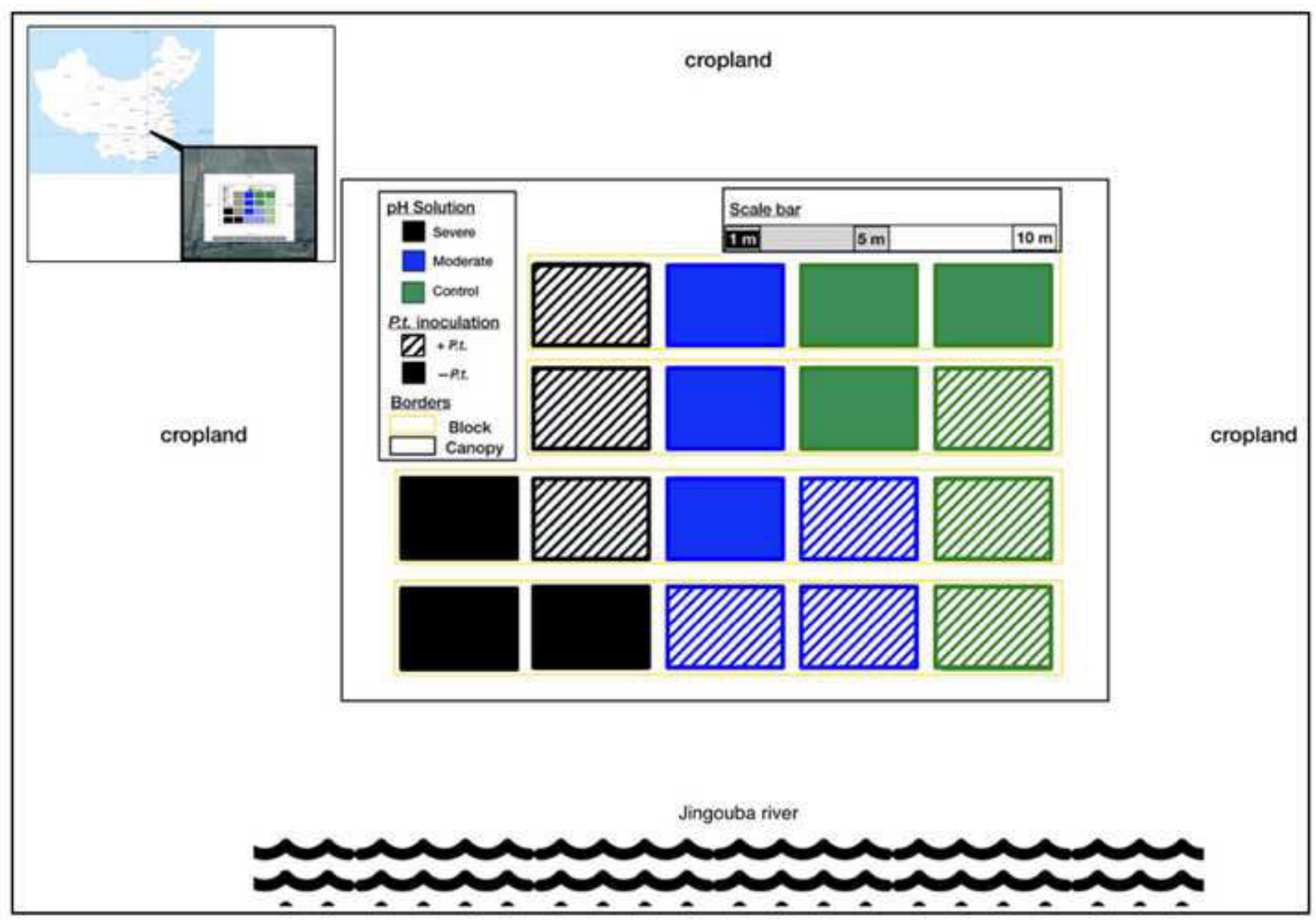


Soil organic matter ( $\log _{2}$-response)

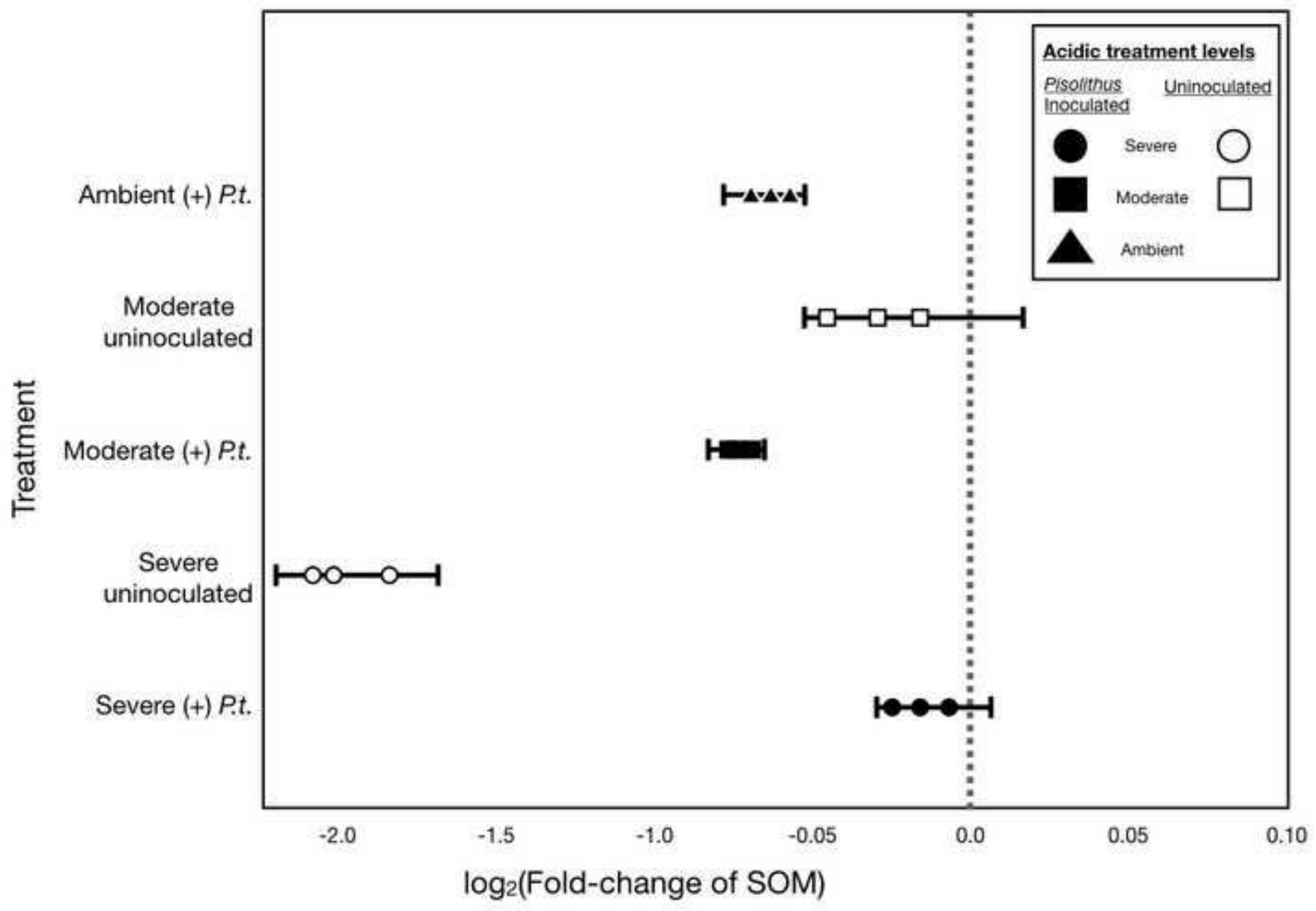


Nitrate ( $\log _{2}$-response)

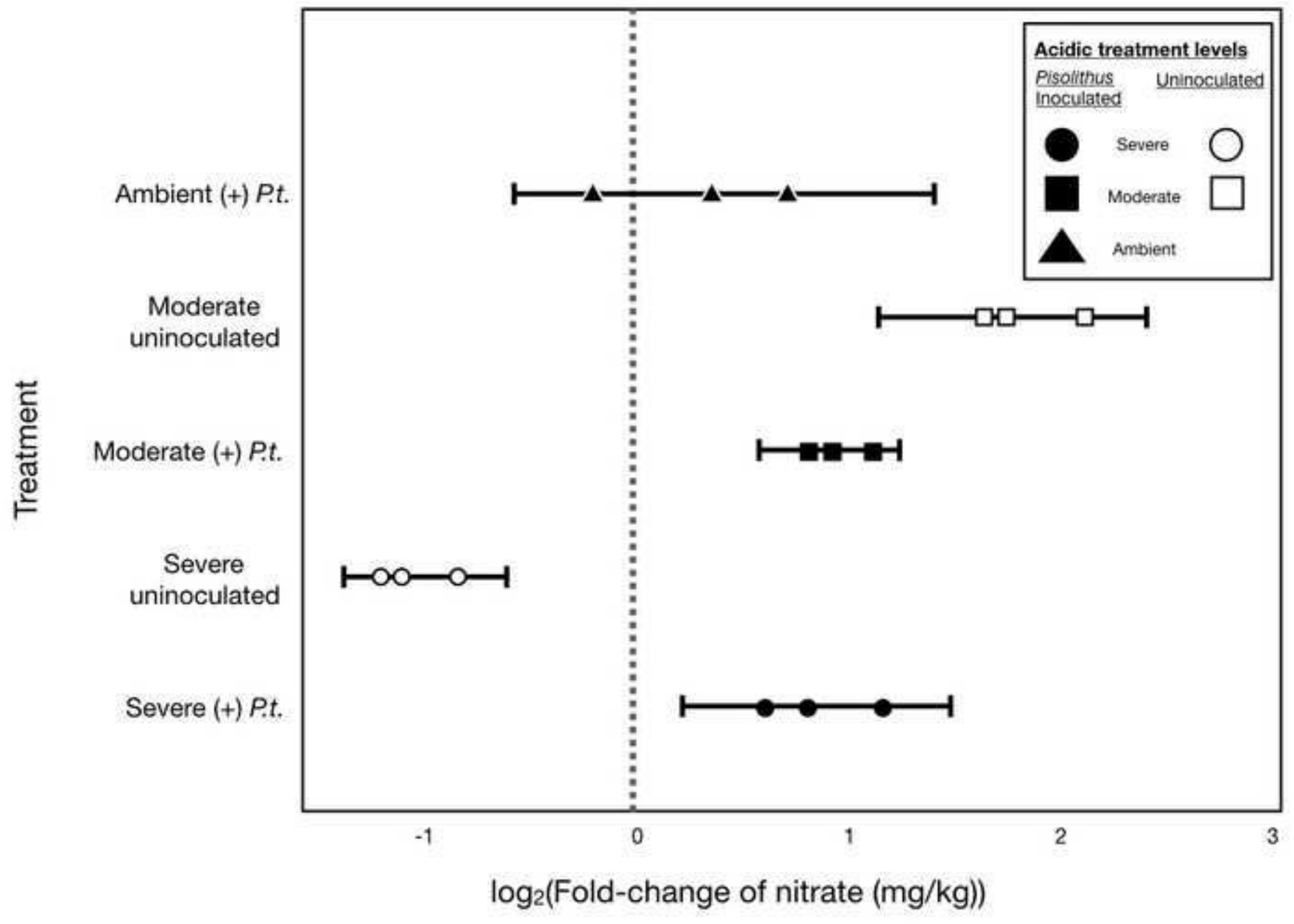


Available P ( $\log _{2}$-response)

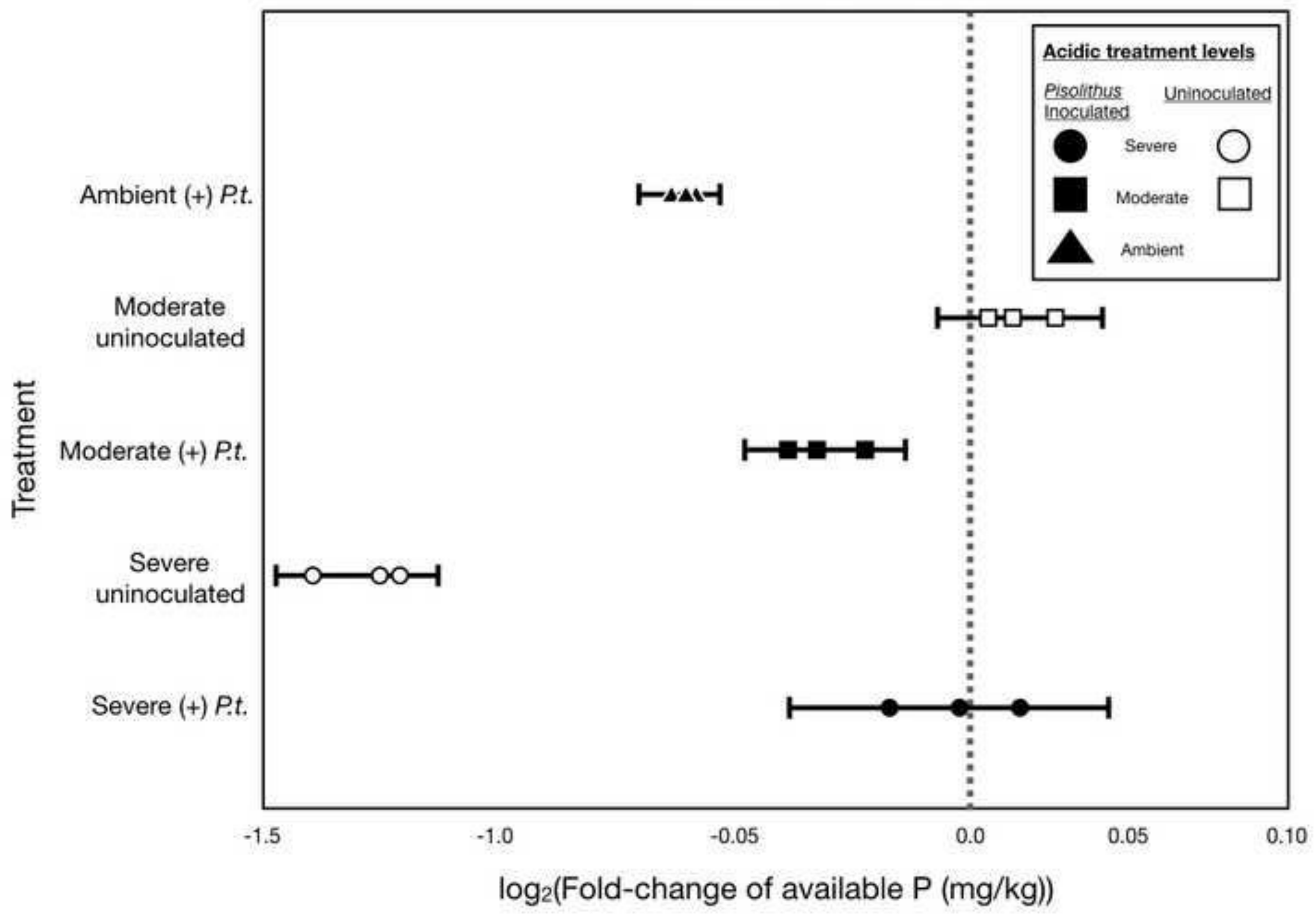


Figure 5. PCoA ITS

Click here to download high resolution image

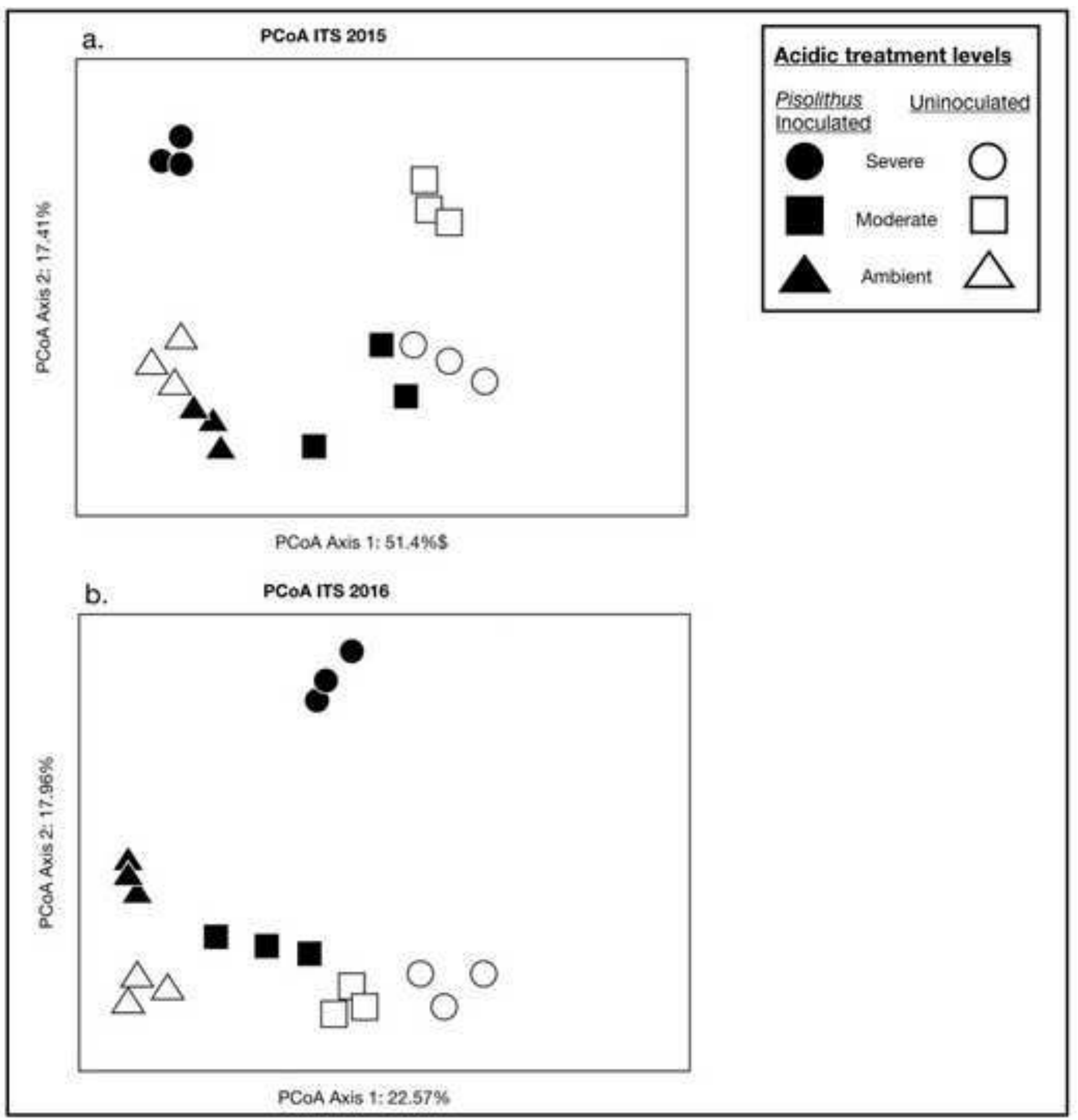

Acidic treatment levels

Pisolithus

noculated

b.

PCOA Axis 1: $22.57 \%$ 
Click here to download high resolution image

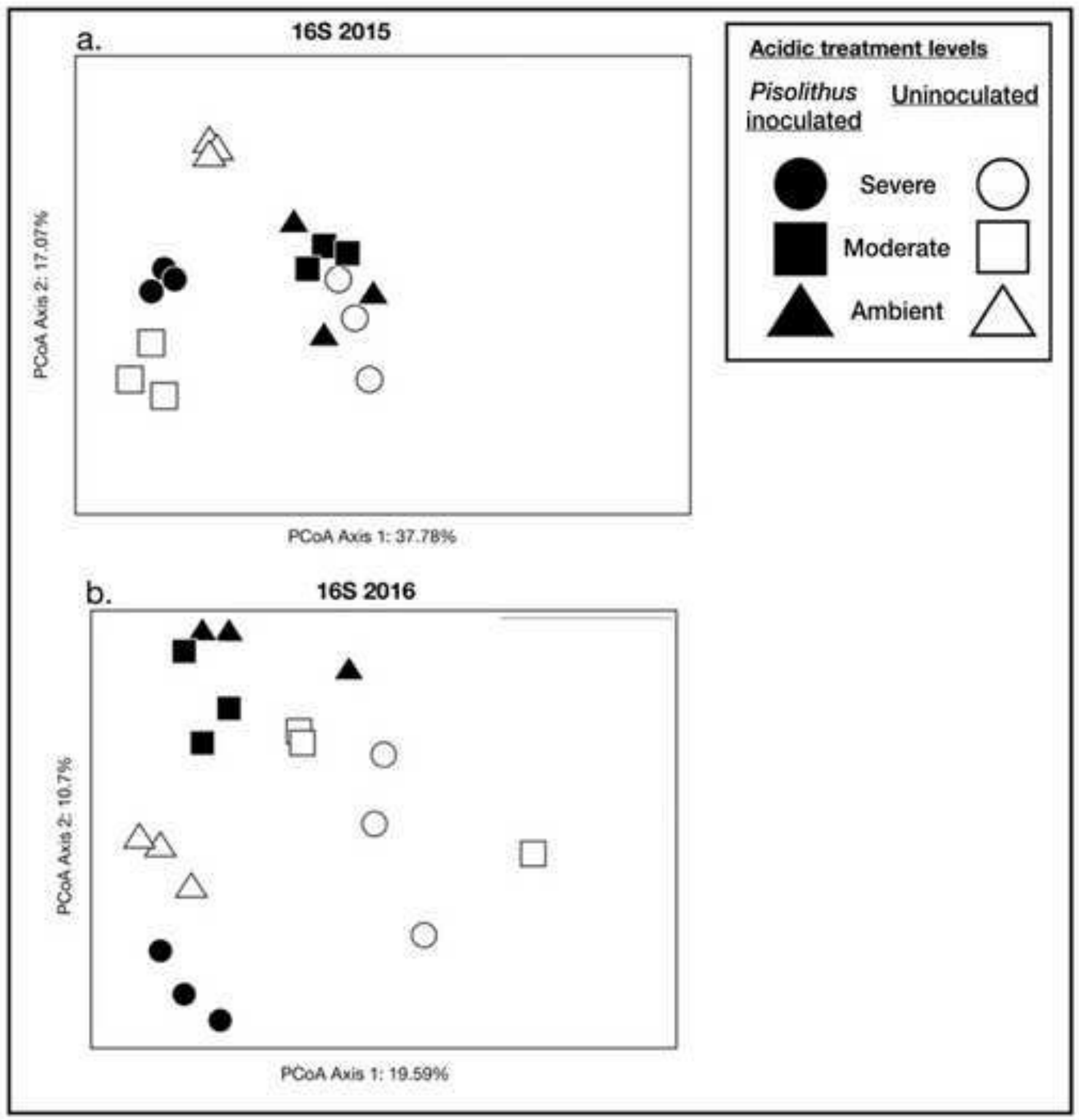


Supplemental info: SI-Fig. 1: NMDS of Fungal Taxa

Click here to download high resolution image

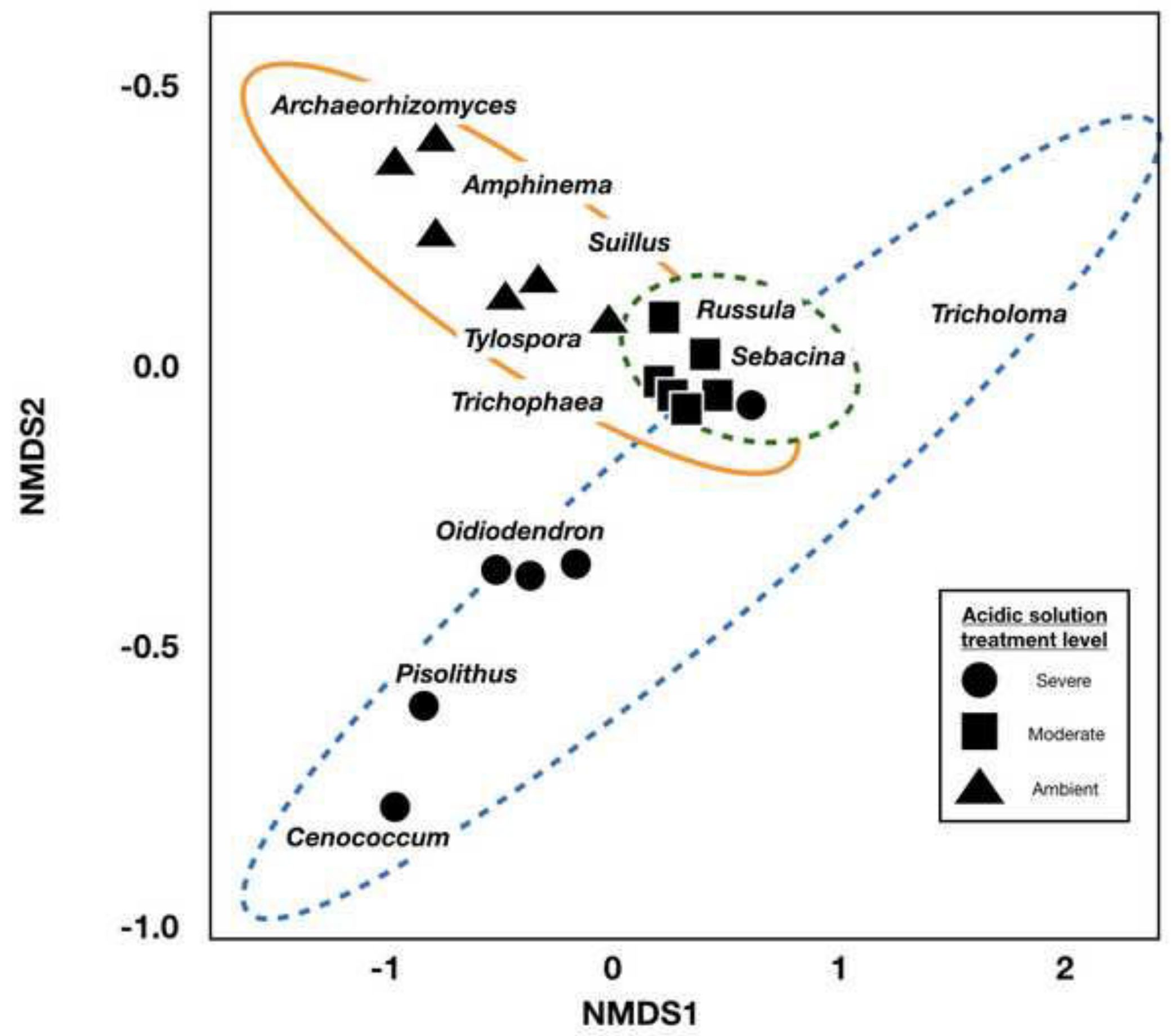




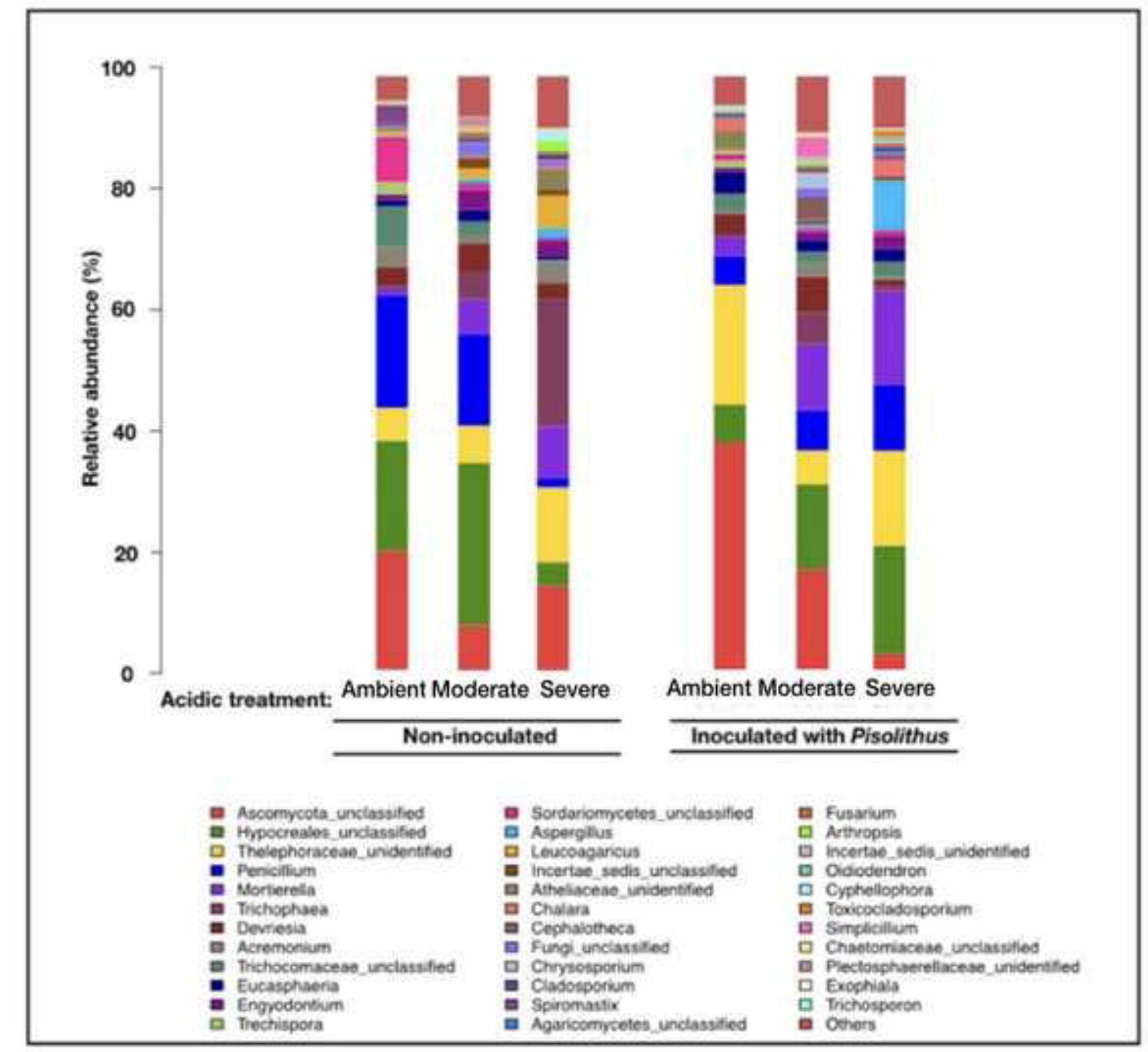




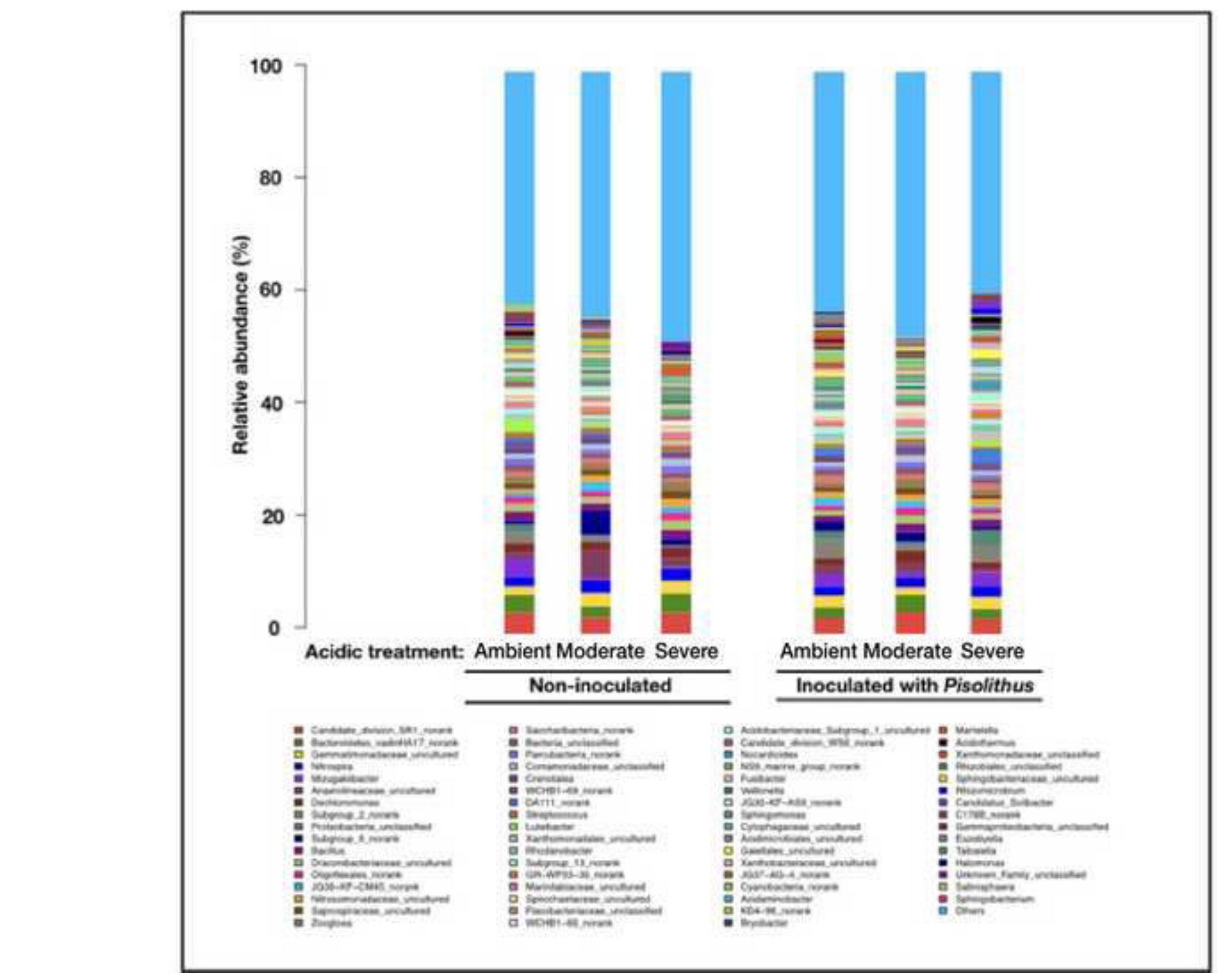

ancionimas

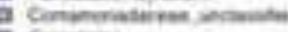

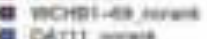

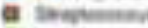

gates

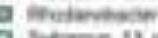

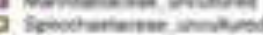

a wivet-en mre

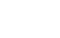

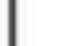

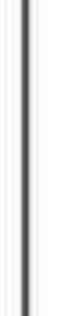

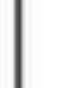

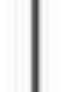

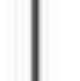


Table 1 Acidic solution $\mathrm{pH}$ and soil $\mathrm{pH}$ across time and among treatment combinations demonstrate shifts, both temporally and by either acidic treatments or Pisolithus inoculation.

\begin{tabular}{|c|c|c|c|}
\hline $\begin{array}{l}\text { pH solution } \\
+/- \text { P.t. (Pisolithus } \\
\text { inoculation) }\end{array}$ & $\begin{array}{c}\text { pH soil } \\
2015 \\
\text { Pre-treatment }\end{array}$ & $\begin{array}{c}\text { pH soil } \\
2015\end{array}$ & $\begin{array}{c}\text { pH soil } \\
2016\end{array}$ \\
\hline $\begin{array}{c}\text { Severe } \\
3.5+\boldsymbol{P} . t .\end{array}$ & $5.03 \pm 0.08$ & $5.46 \pm 0.14$ & $5.57 \pm 0.09$ \\
\hline $\begin{array}{c}\text { Severe } \\
3.5-\end{array}$ & $5.92 \pm 0.08$ & $5.90 \pm 0.13$ & $6.80 \pm 0.09$ \\
\hline $\begin{array}{l}\text { Moderate } \\
4.5+\text { P.t. }\end{array}$ & $5.39 \pm 0.04$ & $5.71 \pm 0.09$ & $6.64 \pm 0.003$ \\
\hline $\begin{array}{c}\text { Moderate } \\
4.5-\end{array}$ & $6.17 \pm 0.12$ & $6.03 \pm 0.06$ & $6.65 \pm 0.04$ \\
\hline $\begin{array}{l}\text { Ambient } \\
5.6+\text { P.t. }\end{array}$ & $6.47 \pm 0.38$ & $6.0 \pm 0.14$ & $6.69 \pm 0.04$ \\
\hline $\begin{array}{c}\text { Ambient } \\
5.6-\end{array}$ & $5.41 \pm 0.17$ & $5.43 \pm 0.39$ & $5.84 \pm 0.13$ \\
\hline
\end{tabular}


Table 2. Pinus massoniana properties shift with acidic treatments and Pisolithus tinctorius inoculation. Values with different letters in the same column indicate significant differences among values in different treatment groups.

\begin{tabular}{|c|c|c|c|c|c|}
\hline $\begin{array}{c}\text { pH solution } \\
+/- \text { P.t. } \\
\text { (Pisolithus } \\
\text { inoculation) } \\
\end{array}$ & $\begin{array}{c}\text { Plant } \\
\text { diameter } \\
(\mathrm{cm})\end{array}$ & $\begin{array}{l}\text { Plant height } \\
\quad(\mathrm{cm})\end{array}$ & $\begin{array}{c}\text { Plant } \\
\text { root:shoot }\end{array}$ & $\begin{array}{l}\text { Dried stem } \\
\text { biomass (g) }\end{array}$ & $\begin{array}{l}\text { Dried needle } \\
\text { biomass (g) }\end{array}$ \\
\hline $\begin{array}{c}\text { Severe } \\
3.5+\text { P.t. }\end{array}$ & $\begin{array}{c}15.37 \pm 0.56 \\
(b, c)\end{array}$ & $\begin{array}{c}116.67 \pm 1.67 \\
\text { (e) }\end{array}$ & $\begin{array}{c}14.31 \pm 2.20 \\
\text { (f) }\end{array}$ & $\begin{array}{c}66.98 \pm 5.42 \\
(b, c)\end{array}$ & $\begin{array}{c}73.29 \pm 5.63 \\
\text { (b) }\end{array}$ \\
\hline $\begin{array}{l}\text { Severe } \\
3.5-\end{array}$ & $\begin{array}{c}13.75 \pm 0.58 \\
\text { (c) }\end{array}$ & $\begin{array}{c}117.33 \pm 3.93 \\
(\mathrm{e})\end{array}$ & $\begin{array}{c}12.62 \pm 0.32 \\
(f, g)\end{array}$ & $\begin{array}{c}60.35 \pm 7.94 \\
\text { (c) }\end{array}$ & $\begin{array}{c}71.88 \pm 13.86 \\
\text { (b) }\end{array}$ \\
\hline $\begin{array}{l}\text { Moderate } \\
4.5+\text { P.t. }\end{array}$ & $\begin{array}{c}18.40 \pm 0.56 \\
\text { (a) }\end{array}$ & $\begin{array}{c}149.33 \pm 3.84 \\
\text { (d) }\end{array}$ & $\begin{array}{c}13.06 \pm 1.24 \\
(f, g)\end{array}$ & $\begin{array}{c}135.07 \pm 8.74 \\
\text { (a) }\end{array}$ & $\begin{array}{c}142.55 \pm 13.08 \\
\text { (a) }\end{array}$ \\
\hline $\begin{array}{l}\text { Moderate } \\
4.5-\end{array}$ & $\begin{array}{c}15.99 \pm 1.43 \\
(b, c)\end{array}$ & $\begin{array}{c}142.00 \pm 4.16 \\
\text { (d) }\end{array}$ & $\begin{array}{c}12.52 \pm 0.21 \\
(\mathrm{f}, \mathrm{g})\end{array}$ & $\begin{array}{c}80.98 \pm 14.56 \\
(b, c)\end{array}$ & $\begin{array}{c}154.25 \pm 5.20 \\
\text { (a) }\end{array}$ \\
\hline $\begin{array}{l}\text { Ambient } \\
+\boldsymbol{P} . t .\end{array}$ & $\begin{array}{c}15.97 \pm 0.36 \\
(b, c)\end{array}$ & $\begin{array}{l}156.33 \pm \\
10.93(d)\end{array}$ & $\begin{array}{c}11.23 \pm 0.61 \\
(\mathrm{f}, \mathrm{g})\end{array}$ & $\begin{array}{c}123.77 \pm 9.59 \\
\text { (a) }\end{array}$ & $\begin{array}{c}136.58 \pm 4.16 \\
\text { (a) }\end{array}$ \\
\hline Ambient - & $\begin{array}{c}17.60 \pm 0.37 \\
(a, b)\end{array}$ & $\begin{array}{c}147.67 \pm 6.74 \\
\text { (d) }\end{array}$ & $\begin{array}{c}10.58 \pm 0.35 \\
(\mathrm{~g})\end{array}$ & $\begin{array}{c}90.21 \pm 6.67 \\
\text { (b) }\end{array}$ & $\begin{array}{c}129.77 \pm 6.87 \\
\text { (a) }\end{array}$ \\
\hline
\end{tabular}




\section{Supplementary Information}

Supplemental SI-Table 1. Spatial arrangement of soil pH through time and by proximity to river. Spatial arrangement ascending in numbers with increasing distance from the Jingouba River

\begin{tabular}{cccc}
$\begin{array}{c}\text { Spatial block } \\
\text { Proximity to River }\end{array}$ & $\begin{array}{c}\mathbf{p H} \text { soil } \\
2015 \\
\text { Pre-treatment }\end{array}$ & $\begin{array}{c}\mathbf{p H} \text { soil } \\
2015\end{array}$ & $\begin{array}{c}\mathbf{p H} \text { soil } \\
2016\end{array}$ \\
\hline one & $5.52 \pm 0.37$ & $5.69 \pm 0.18$ & $5.96 \pm 0.34$ \\
two & $5.65 \pm 0.26$ & $5.65 \pm 0.18$ & $6.31 \pm 0.28$ \\
three & $5.99 \pm 0.48$ & $5.72 \pm 0.17$ & $6.58 \pm 0.20$ \\
four & $5.85 \pm 0.23$ & $5.99 \pm 0.13$ & $6.71 \pm 0.08$
\end{tabular}


Supplemental SI Table 2: Soil nutrients in our plots treated with acidic treatments and inoculated with Pisolithus in both 2015 and 2016.

\begin{tabular}{|c|c|c|c|c|c|c|c|c|c|c|}
\hline \multirow{2}{*}{$\begin{array}{c}\text { pH } \\
\text { solution } \\
+/- \text { P.t. } \\
\text { (Pisolithus } \\
\text { inoculation) }\end{array}$} & \multicolumn{2}{|c|}{$\begin{array}{l}\text { Available P } \\
\left(\mathrm{mg} \mathrm{kg}^{-1}\right)\end{array}$} & \multicolumn{2}{|c|}{$\begin{array}{c}\text { Available } \\
\text { K } \\
\left(\mathrm{mg} \mathrm{kg}^{-1}\right)\end{array}$} & \multicolumn{2}{|c|}{$\begin{array}{c}\mathrm{NH}_{4}-\mathrm{N} \\
\left(\mathrm{mg} \mathrm{kg}^{-1}\right)\end{array}$} & \multicolumn{2}{|c|}{$\begin{array}{c}\mathrm{NO}_{3}-\mathrm{N} \\
\left(\mathrm{mg} \mathrm{kg}^{-1}\right)\end{array}$} & \multicolumn{2}{|c|}{$\begin{array}{l}\text { Soil organic matter } \\
\qquad\left(\mathrm{mg} \mathrm{kg}^{-1}\right)\end{array}$} \\
\hline & 2015 & 2016 & 2015 & 2016 & 2015 & 2016 & 2015 & 2016 & 2015 & 2016 \\
\hline $\begin{array}{c}\text { Severe } \\
3.5 \\
+ \text { P.t. }\end{array}$ & $\begin{array}{r}9.0 \pm \\
0.31\end{array}$ & $\begin{array}{l}14.09 \pm \\
0.76\end{array}$ & $\begin{array}{r}193.33 \pm \\
6.36\end{array}$ & $\begin{array}{l}211.0 \pm \\
7.09\end{array}$ & $\begin{array}{r}7.92 \pm \\
0.58\end{array}$ & $\begin{array}{l}9.22 \pm \\
2.01\end{array}$ & $\begin{array}{r}239.78 \pm \\
5.2\end{array}$ & $\begin{array}{l}344.47 \pm \\
39.87\end{array}$ & $\begin{array}{r}17.75 \pm \\
0.20\end{array}$ & $\begin{array}{l}19.27 \pm \\
0.29\end{array}$ \\
\hline $\begin{array}{l}\text { Severe } \\
3.5-\end{array}$ & $6.0 \pm 0.2$ & $\begin{array}{l}6.02 \pm \\
0.18\end{array}$ & $\begin{array}{r}160.33 \pm \\
13.57\end{array}$ & $\begin{array}{l}127.67 \pm \\
2.91\end{array}$ & $\begin{array}{r}1.97 \pm \\
0.15\end{array}$ & $\begin{array}{l}1.50 \pm \\
1.50\end{array}$ & $\begin{array}{r}118.54 \pm \\
0.88\end{array}$ & $\begin{array}{l}88.54 \pm \\
6.31\end{array}$ & $\begin{array}{r}11.82 \pm \\
0.17\end{array}$ & $\begin{array}{l}5.44 \pm \\
0.25\end{array}$ \\
\hline $\begin{array}{c}\text { Moderate } \\
\quad 4.5 \\
+ \text { P.t. }\end{array}$ & $\begin{array}{r}9.83 \pm \\
1.54\end{array}$ & $\begin{array}{l}11.73 \pm \\
0.76\end{array}$ & $\begin{array}{r}163.67 \pm \\
5.23\end{array}$ & $\begin{array}{l}175.00 \pm \\
4.04\end{array}$ & $\begin{array}{r}3.73 \pm \\
0.11\end{array}$ & $\begin{array}{l}8.41 \pm \\
2.40\end{array}$ & $\begin{array}{r}153.78 \pm \\
5.53\end{array}$ & $\begin{array}{l}367.89 \pm \\
23.16\end{array}$ & $\begin{array}{r}13.22 \pm \\
0.59\end{array}$ & $\begin{array}{l}13.0 \pm \\
0.01\end{array}$ \\
\hline $\begin{array}{c}\text { Moderate } \\
4.5-\end{array}$ & $\begin{array}{r}11.83 \pm \\
1.17\end{array}$ & $\begin{array}{l}15.57 \pm \\
0.42\end{array}$ & $\begin{array}{r}205.33 \pm \\
12.17\end{array}$ & $\begin{array}{l}259.33 \pm \\
1.67\end{array}$ & $\begin{array}{r}3.96 \pm \\
0.39\end{array}$ & $\begin{array}{l}7.38 \pm \\
1.82\end{array}$ & $\begin{array}{r}275.32 \pm \\
4.08\end{array}$ & $\begin{array}{l}708.19 \pm \\
85.50\end{array}$ & $\begin{array}{r}19.94 \pm \\
0.65\end{array}$ & $\begin{array}{l}17.60 \pm \\
0.96\end{array}$ \\
\hline $\begin{array}{l}\text { Ambient } \\
+\boldsymbol{P} . t\end{array}$ & $\begin{array}{r}7.03 \pm \\
0.28\end{array}$ & $\begin{array}{l}9.51 \pm \\
0.12\end{array}$ & $\begin{array}{r}169.33 \pm \\
0.67\end{array}$ & $\begin{array}{l}200.0 \pm \\
4.62\end{array}$ & $\begin{array}{r}1.83 \pm \\
0.22\end{array}$ & $\begin{array}{l}4.06 \pm \\
1.24\end{array}$ & $\begin{array}{r}56.26 \pm \\
3.35\end{array}$ & $\begin{array}{l}227.35 \pm \\
44.40\end{array}$ & $\begin{array}{r}13.06 \pm \\
0.27\end{array}$ & $\begin{array}{l}13.79 \pm \\
0.19\end{array}$ \\
\hline $\begin{array}{c}\text { Ambient } \\
-\end{array}$ & $\begin{array}{r}14.45 \pm \\
0.47\end{array}$ & $\begin{array}{l}13.28 \pm \\
0.18\end{array}$ & $\begin{array}{r}207.67 \pm \\
2.63\end{array}$ & $\begin{array}{l}244.67 \pm \\
1.33\end{array}$ & $\begin{array}{r}3.58 \pm \\
0.32\end{array}$ & $\begin{array}{l}12.80 \pm \\
1.35\end{array}$ & $\begin{array}{r}180.32 \pm \\
26.02\end{array}$ & $\begin{array}{l}879.68 \pm \\
34.12\end{array}$ & $\begin{array}{r}20.05 \pm \\
0.20\end{array}$ & $\begin{array}{l}17.81 \pm \\
0.83\end{array}$ \\
\hline
\end{tabular}


Supplementary Table. Soil properties from 2015 in our plots treated with acidic treatments and inoculated with Pisolithus. Elemental analyses included sodium $(\mathrm{Na})$, calcium $(\mathrm{Ca})$, magnesium $(\mathrm{Mg})$, and aluminum (Al), as well as cation exchange capacity (CEC).

\begin{tabular}{|c|c|c|c|c|c|}
\hline $\begin{array}{c}\text { pH solution } \\
+/- \text { P.t. } \\
\text { (Pisolithus } \\
\text { inoculation) }\end{array}$ & $\begin{array}{c}\mathrm{Na} \\
\left(\mathrm{cmol} \mathrm{kg}^{-1}\right)\end{array}$ & $\begin{array}{c}\mathrm{Ca} \\
\left(\mathrm{cmol} \mathrm{kg}^{-1}\right)\end{array}$ & $\begin{array}{c}\text { Mg } \\
\left(\mathrm{cmol} \mathrm{kg}^{-1}\right)\end{array}$ & $\begin{array}{c}\mathrm{Al} \\
\left(\mathrm{mg} \mathrm{kg}^{-1}\right)\end{array}$ & $\begin{array}{c}\text { CEC } \\
\left(\mathrm{cmol} \mathrm{kg}^{-1}\right)\end{array}$ \\
\hline $\begin{array}{c}\text { Severe } \\
3.5+\text { P.t. }\end{array}$ & $1.0 \pm 0.06$ & $6.45 \pm 0.14$ & $0.42 \pm 0.02$ & $7.02 \pm 2.19$ & $7.08 \pm 0.98$ \\
\hline $\begin{array}{c}\text { Severe } \\
3.5-\end{array}$ & $0.75 \pm 0.04$ & $5.57 \pm 0.16$ & $0.95 \pm 0.05$ & $2.12 \pm 0.27$ & $7.69 \pm 0.08$ \\
\hline $\begin{array}{l}\text { Moderate } \\
4.5+\text { P.t. }\end{array}$ & $0.67 \pm 0.02$ & $4.42 \pm 0.07$ & $1.25 \pm 0.36$ & $3.23 \pm 0.29$ & $8.54 \pm 0.43$ \\
\hline $\begin{array}{c}\text { Moderate } \\
4.5-\end{array}$ & $0.85 \pm 0.11$ & $8.22 \pm 0.97$ & $0.44 \pm 0.01$ & $1.66 \pm 0.09$ & $8.49 \pm 0.41$ \\
\hline $\begin{array}{l}\text { Ambient } \\
+\boldsymbol{P} . t .\end{array}$ & $0.73 \pm 0.03$ & $4.95 \pm 0.09$ & $0.57 \pm 0.01$ & $2.52 \pm 0.99$ & $8.3 \pm 1.35$ \\
\hline Ambient - & $0.61 \pm 0.01$ & $5.12 \pm 0.70$ & $0.39 \pm 0.01$ & $6.34 \pm 1.3$ & $7.76 \pm 0.77$ \\
\hline
\end{tabular}


Supplemental SI-Table 4. Bacterial community diversity metrics from 2016. Metrics include: Abundance-based Coverage Estimate (ACE), Chao1, Fisher, Observed OTUs, Shannon, and Simpsons.

\begin{tabular}{|c|c|c|c|c|c|c|}
\hline $\begin{array}{c}\text { pH } \\
\text { solution } \\
+/- \text { P.t. } \\
\text { (Pisolithus } \\
\text { inoculation) }\end{array}$ & ACE & Chao1 & Fisher & $\begin{array}{c}\text { Observed } \\
\text { OTUs }\end{array}$ & Shannon & Simpson \\
\hline $3.5+$ P.t. & $\begin{array}{c}2642.04 \pm \\
24.75\end{array}$ & $\begin{array}{c}2639.84 \pm \\
50.80\end{array}$ & $\begin{array}{c}601.62 \pm \\
12.03\end{array}$ & $\begin{array}{c}2178.67 \pm \\
31.84\end{array}$ & $\begin{array}{l}6.57 \pm \\
0.019\end{array}$ & $\begin{array}{l}0.995 \pm \\
0.0003\end{array}$ \\
\hline $3.5-$ & $\begin{array}{c}2587.61 \pm \\
24.06\end{array}$ & $\begin{array}{c}2625.95 \pm \\
51.97\end{array}$ & $\begin{array}{c}594.80 \pm \\
26.17\end{array}$ & $\begin{array}{c}2159.67 \pm \\
70.11\end{array}$ & $\begin{array}{l}6.53 \pm \\
0.069\end{array}$ & $\begin{array}{l}0.997 \pm \\
0.0004\end{array}$ \\
\hline $4.5+$ P.t. & $\begin{array}{c}2868.45 \pm \\
25.69\end{array}$ & $\begin{array}{c}2883.93 \pm \\
54.57\end{array}$ & $\begin{array}{c}672.13 \pm \\
11.16\end{array}$ & $\begin{array}{c}2361.67 \pm \\
28.48\end{array}$ & $\begin{array}{l}6.73 \pm \\
0.028\end{array}$ & $\begin{array}{l}0.997 \pm \\
0.0001\end{array}$ \\
\hline $4.5-$ & $\begin{array}{c}2793.60 \pm \\
25.45\end{array}$ & $\begin{array}{c}2796.59 \pm \\
52.2\end{array}$ & $\begin{array}{c}652.28 \pm \\
37.44\end{array}$ & $\begin{array}{c}2309 \pm \\
97.22\end{array}$ & $\begin{array}{l}6.74 \pm \\
0.113\end{array}$ & $\begin{array}{l}0.997 \pm \\
0.0006\end{array}$ \\
\hline $\begin{array}{l}5.6+\text { P.t. } \\
\text { (Ambient) }\end{array}$ & $\begin{array}{c}2875.35 \pm \\
25.04\end{array}$ & $\begin{array}{c}2887.16 \pm \\
57.23\end{array}$ & $\begin{array}{c}662.43 \pm \\
23.08\end{array}$ & $\begin{array}{c}2336.33 \pm \\
63.38\end{array}$ & $\begin{array}{l}6.70 \pm \\
0.046\end{array}$ & $\begin{array}{l}0.997 \pm \\
0.0001\end{array}$ \\
\hline $\begin{array}{c}5.6- \\
\text { (Ambient) }\end{array}$ & $\begin{array}{c}2696.85 \pm \\
25.31\end{array}$ & $\begin{array}{c}2694.06 \pm \\
55.28\end{array}$ & $\begin{array}{c}600.43 \pm \\
5.96\end{array}$ & $\begin{array}{c}2175.67 \pm \\
15.76\end{array}$ & $\begin{array}{l}6.48 \pm \\
0.025\end{array}$ & $\begin{array}{l}0.995 \pm \\
0.0004\end{array}$ \\
\hline
\end{tabular}


Supplemental SI-Table 5. Fungal community diversity metrics from 2016. Metrics include: Abundance-based Coverage Estimate (ACE), Chao1, Fisher, Observed OTUs, Shannon, and Simpsons.

\begin{tabular}{|c|c|c|c|c|c|c|}
\hline $\begin{array}{c}\text { pH } \\
\text { solution } \\
+/- \text { P.t. } \\
\text { (Pisolithus } \\
\text { inoculation) }\end{array}$ & $\mathbf{A C E}$ & Chao1 & Fisher & $\begin{array}{c}\text { Observed } \\
\text { OTUs }\end{array}$ & Shannon & Simpson \\
\hline $3.5+$ P.t. & $\begin{array}{c}480.39 \pm \\
20.43\end{array}$ & $\begin{array}{c}477.28 \pm \\
16.31\end{array}$ & $\begin{array}{c}63.31 \pm \\
3.42\end{array}$ & $\begin{array}{c}389.0 \pm \\
17.06\end{array}$ & $\begin{array}{l}3.03 \pm \\
0.079\end{array}$ & $\begin{array}{l}0.84 \pm \\
0.006\end{array}$ \\
\hline $3.5-$ & $\begin{array}{c}439.98 \pm \\
8.91\end{array}$ & $\begin{array}{c}451.29 \pm \\
7.95\end{array}$ & $\begin{array}{c}56.54 \pm \\
0.88\end{array}$ & $\begin{array}{c}353.67 \pm \\
4.48\end{array}$ & $2.97 \pm 0.2$ & $\begin{array}{l}0.89 \pm \\
0.013\end{array}$ \\
\hline $4.5+$ P.t. & $\begin{array}{c}538.29 \pm \\
29.61\end{array}$ & $\begin{array}{c}541.03 \pm \\
37.33\end{array}$ & $\begin{array}{c}75.36 \pm \\
2.06\end{array}$ & $\begin{array}{c}450.0 \pm \\
10.26\end{array}$ & $3.73 \pm 0.04$ & $\begin{array}{l}0.94 \pm \\
0.005\end{array}$ \\
\hline $4.5-$ & $\begin{array}{c}496.21 \pm \\
18.22\end{array}$ & $\begin{array}{c}475.001 \pm \\
17.34\end{array}$ & $\begin{array}{c}67.94 \pm \\
2.70\end{array}$ & $\begin{array}{c}412.67 \pm \\
13.67\end{array}$ & $3.35 \pm 0.02$ & $\begin{array}{l}0.90 \pm \\
0.011\end{array}$ \\
\hline $\begin{array}{l}5.6+\text { P.t. } \\
\text { (Ambient) }\end{array}$ & $\begin{array}{c}540.38 \pm \\
22.99\end{array}$ & $\begin{array}{c}523.13 \pm \\
25.7\end{array}$ & $\begin{array}{c}75.58 \pm \\
2.81\end{array}$ & $\begin{array}{c}451.0 \pm \\
14.47\end{array}$ & $3.58 \pm 0.09$ & $0.93 \pm 0.01$ \\
\hline $\begin{array}{c}5.6- \\
\text { (Ambient) }\end{array}$ & $\begin{array}{c}429.08 \pm \\
17.88\end{array}$ & $\begin{array}{c}428.87 \pm \\
14.51\end{array}$ & $\begin{array}{c}65.11 \pm \\
3.35\end{array}$ & $\begin{array}{c}398.0 \pm \\
17.57\end{array}$ & $3.63 \pm 0.12$ & $\begin{array}{l}0.92 \pm \\
0.011\end{array}$ \\
\hline
\end{tabular}




\section{Supplemental molecular methods: SI}

We extracted total DNA from each of the three $0.25 \mathrm{~g}$ soil aliquots using an E.Z.N.A. ${ }^{\circledR}$ soil DNA Kit (Omega Bio-tek, Norcross, GA, U.S.) according to manufacturer's protocols. We pooled these DNA extracts into a single representative DNA extract and subsequently standardized concentrations to $10 \mathrm{ng} / \mu \mathrm{l}$ before Polymerase chain reactions (PCR) amplification. We targeted hypervariable portions of both the V3-V4 region of the bacterial 16S rRNA gene and the fungal internal transcribed spacer (fungal ITS1) region using primers modified for Illumina Miseq sequencing (Illumina Incorporated, California).

For bacteria, the V3-V4 region of $16 \mathrm{~S}$ was amplified using forward primer 338F (5'ACTCCTACGGGAGGCAGCAG-3) and reverse primer 806R (5’-

GGACTACHVGGGTWTCTAAT-3'), along with a unique eight-base barcode assigned to each sample. For fungi, the internal transcribed spacer region was amplified with forward primer ITS 1 (5' - CTTGGTCATTTAGAGGAAGTAA-3') and reverse primer 2043R (5' GCTGCGTTCTTCATCGATGC-3'). Fungal ITS1 region was targeted, along with unique molecular barcodes assigned to each reverse primer. For both $16 \mathrm{~S}$ and ITS1, polymerase chain reactions were set up in triplicate using $0.8 \mu \mathrm{l}$ of each primer $(5 \mu \mathrm{M}), 0.4 \mu \mathrm{L}$ of FastPfu Polymerase, $10 \mathrm{ng}$ of DNA template, $2 \mu \mathrm{L}$ of $2.5 \mathrm{mM}$ dNTPs, $4 \mu \mathrm{L}$ of $5 \times$ FastPfu Buffer. Reactions ran for $95^{\circ} \mathrm{C}$ for $3 \mathrm{~min}$, followed by 25 cycles at $95^{\circ} \mathrm{C}$ for $30 \mathrm{~s}, 55^{\circ} \mathrm{C}$ for $30 \mathrm{~s}$, and 72 ${ }^{\circ} \mathrm{C}$ for $30 \mathrm{~s}$ and a final extension at $72{ }^{\circ} \mathrm{C}$ for $10 \mathrm{~min}$.

Both 16S and ITS, PCR amplicons were visualized using gel electrophoresis, and subsequently extracted from 2\% agarose gels. Amplicons were purified using a AxyPrep DNA Gel Extraction Kit (Axygen Biosciences, Union City, California) according to the manufacturer's instructions, and then quantified in individual tubes using QuantiFluor ${ }^{\mathrm{TM}}$-ST 
(Promega, Madison, Wisconsin). Purified amplicons were pooled in equimolar concentrations for downstream Illumina sequencing.

Our PCR products were sequenced on an Illumina MiSeq flowcell by Shanghai Majorbio (Shanghai, China) and paired-end sequences were generated $(2 \times 300)$ according to the standard protocols. Raw fastq files were demultiplexed, quality-filtered using QIIME (version 1.17); 300 basepair (bp) reads were truncated at quality scores $<20$ over a $50 \mathrm{bp}$ range and truncated reads shorter than 50bp were discarded. Barcode matching allowed for any two nucleotide base mismatches, however, reads containing ambiguous characters were removed. Only sequences overlapping longer than $10 \mathrm{bp}$ were assembled according to their overlap sequence. Operational Units (OTUs) were clustered with 97\% similarity cutoff using UPARSE (version 7.1 http://drive5.com/uparse/) (Edgar 2013). Chimeric sequences were identified and removed using UCHIME. Taxonomic information associated with each 16S rRNA gene sequence was analyzed by RDP Classifier (http://rdp.cme.msu.edu/) against the Silva (SSU115) 16S rRNA database and taxonomy of each ITS1 gene sequence was analyzed by RDP Classifier (http://rdp.cme.msu.edu/) against the UNITE 7.0 database.

\section{Reference:}

Edgar, R.C. 2013. UPARSE: highly accurate OTU sequences from microbial amplicon reads. Nat Methods 10: 996. doi:10.1038/Nmeth.2604. 